\title{
ON THE MAGNITUDE OF THE GODS IN MATERIALIST THEOLOGY AND GREEK ART
}

\author{
GUY HEDREEN \\ Williams College*
}

\section{For David Lang and Suzanne Bocranegra}

\begin{abstract}
In this paper, I address one characteristic of Classical Greek votive reliefs that has troubled scholars: the size of the gods. The reliefs depict mortal worshippers approaching gods and goddesses who are, almost invariably, larger in stature than the mortals. Scholars have generally explained the difference in scale to be art historical, rather than theological, in significance. Either the larger scale is a visual expression of the hierarchical superiority of the gods or the images of the gods represent over-life-size statues. In addition, it is widely accepted that votive reliefs are products of unsophisticated religious belief, ignorant of the conceptualization of an imperceptible, non-corporeal deity in Classical philosophy. In this paper, I accept the artistic proposition of votive reliefs at face value: in this genre, the gods are living, visible, material bodies, most often anthropomorphic in form and always larger in magnitude than mortals. I identify one significant parallel for this interpretation within Greek and Roman thought, namely, the conception of gods within the materialist theology developed by the late Classical writer Epicurus and, in part at least, by the fifth-century BC writer Demokritos. In the writings of the Epicureans and, it appears, the atomists, as in the votive reliefs, gods are human in form, very beautiful, self-sufficient, larger than humans in size and known by mortals through visual perception.
\end{abstract}

Keywords: Greek votive reliefs, gods, visual perception theory, ancient Greek theology, Greek religion

\section{Introduction}

On a Classical Athenian carved sculptural relief of around $410 \mathrm{BC}$ (fig. 1), the most surprising representational feature is the difference in scale between the figures. ${ }^{1}$ In the right half of the relief are three beautifully dressed anthropomorphic female figures. In height, they reach to the very edge of the crown moulding. To the left, standing in front of an altar, is a bearded male figure barely half the height of the female figures. Above the man, in the space created by his diminutive scale, peering out of a cave, is a bearded male hybrid human-animal with horns growing from his head. The identification of the figures is provided by the dedicatory inscription: the man is Archandros, the female figures are goddesses known as Nymphs, the compound creature is the goat-god Pan. The Nymph to the left acknowledges the presence of Archandros visually. But she also drapes her arm casually and affectionately over the shoulder of the Nymph in the middle, who stares off into space, or perhaps towards her sister on the right. The poses and gazes of the Nymphs suggest the absence of agenda or even much interest in what is going on around them. The mood is underscored by the casual pose of Pan, which suggests that he is at home. All of the deities appear as if they might have been here, in this place, for a long time. Not so the figure of Archandros, who steps forward on his left foot, as if just arriving, and raises his right hand in an emphatic gesture. The gesture has been variously interpreted as one of prayer, greeting or reverence; but the one thing I believe one may safely say is that it is a response to the perceptual presence of the deities. It is as if he himself has just been granted, at this moment, a vision of what we, as beholders of the relief, are afforded as well: the god and goddesses in their authentic, timeless, blessed existence.

* ghedreen@williams.edu. For helpful comments on drafts of this paper, I thank Alan Shapiro, Milette Gaifman, Michael Flower and several anonymous readers. I also thank Douglas Cairns and Lin Foxhall for editorial help. In this paper, LM = Laks and Most (2016).
1 Athens, NM 1329, found in the Asklepieion at Athens, but perhaps originally from the sanctuary of the Nymph (Edwards (1985) 293-303). The dedication, Archandros Numphais ka[i Pani], 'Archandros to the Nymphs an[d Pan]', is $I G \mathrm{II}^{2} 4545$. 


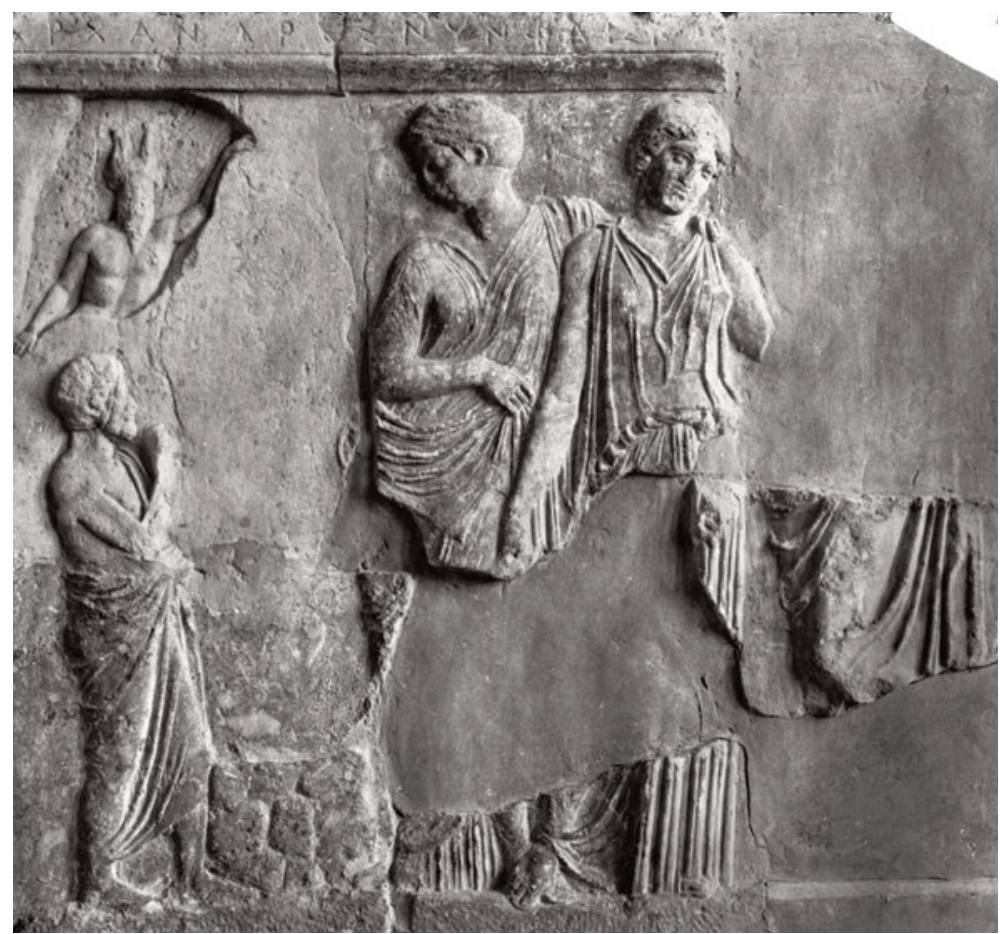

Fig. 1. Archandros relief, Attic votive relief, Athens NM 1329, ca. 410 BC (photograph copyright Bildarchiv Foto Marburg/Art Resource, NY).

Beginning sporadically in the Archaic period, then very frequently in the Classical period and ending in the Imperial Roman age, worshippers dedicated sculptural reliefs like the Archandros slab, in which both mortal worshipper(s) and immortal recipient(s) of the offerings appear within the same virtual, representational space. There is great variety in the number and gender of the mortal donors, the identity and number of the gods depicted, the regions of Greece in which they were made and dedicated (though the greatest number are from Attica), and the quality of the carving. ${ }^{2}$ Very occasionally, the deity takes the form of an animal. But the very great majority of votive reliefs are characterized by a few common features: the naturalistic, anthropomorphic form taken by the gods, the quietude of their demeanour, the visual nature of the encounter for mortals and the relatively larger scale of the gods compared to the mortal figures. Within Greek art more generally, gods have many different forms and sizes, from fully anthropomorphic to aniconic, and diminutive to colossal. ${ }^{3}$ But within the genre of votive reliefs, they are more narrowly defined.

In a telling formulation, Anja Klöckner concludes that the gods depicted on votive reliefs should be understood to be present 'not as statues, but personally present' and yet, she demurs, 'it would be naive to understand these images literally'. The purpose of my paper is to test that claim. Is it productive to consider, as a working hypothesis, that the images were indeed understood literally? ${ }^{4}$ If so, a viewer might explicate a votive relief thus: 'the worshippers in this relief are actually seeing the gods and goddesses themselves, and those deities turn out to be larger in size than the mortals'. In other words, ancient viewers understood the differential in scale between mortal and immortal figures to be of genuine theological significance, and not merely an art historical phenomenon.

\footnotetext{
2 For an overview of votive reliefs, see Vikela (2004). For a sense of the broad geographical range of the material, see Comella (2002). The fullest study of Attic votive reliefs to Pan and the Nymphs remains
} 


\section{A brief history of scholarship on the magnitude of the gods in votive reliefs}

Two features of votive reliefs in particular, the differential in scale and the visual nature of the encounter, have troubled scholars. Martin Robertson observes that the difference in scale between gods and mortals in Archaic votive reliefs is unproblematic because it is part of 'formal convention'; on the Classical Archandros relief (fig. 1), because of the 'naturalism' of the figures, the difference is 'much more strange'. ${ }^{5}$ Nikolaus Himmelmann identifies the visual perception of the over-humansized gods by the mortal worshippers in votive reliefs as the root of the problem. On the Parthenon frieze, the divine figures are depicted on a larger scale than the mortal figures, but the size differential can be understood to be a symbolic convention for indicating the greater importance of the gods, because the mortals do not acknowledge the gods; they are not eyewitnesses to their large size. ${ }^{6}$ On the relief in Athens, Archandros reveals through his gesture that he is actually seeing the goddesses with his own eyes, and therefore can very well be imagined to be thinking something like: 'Wow, that is what the goddesses actually look like, and they are almost twice as tall as I am.'

Himmelmann described votive reliefs as 'reflections of popular religion'. In part, he had in mind the modest size of the dedications and the rustic nature of the recipients (often, the Nymphs and Pan), but he may also have thought that the underlying theology, in which gods are materially embodied, visible to mortals and nearly twice as tall, is intellectually unsophisticated. That is the opinion of Ulrich Hausmann presented in the first important study of votive reliefs. The 'simple piety' of the 'common folk' led them to accept in the reliefs they commissioned the presence of a mortal donor on a diminutive scale within the same space as the immortal gods, which was never accepted in 'great' art. ${ }^{7}$ Gerhard Neumann, in a subsequent, even more detailed study, emphasizes the gap between the 'earnest piety' expressed by the imagery on votive reliefs and the religious scepticism of Classical philosophers. ${ }^{8}$ Not merely sophists like Protagoras, who is reported to have said, 'about the gods I am able to know neither that they exist nor that they do not exist nor of

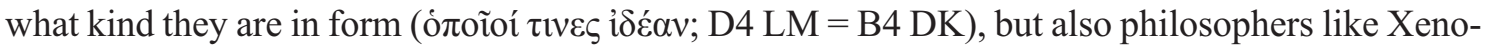
phanes, Socrates and Plato, were committed to the idea that the gods were not visible to mortals in an anthropomorphic, bodily sense. ${ }^{9}$ The implication of the arguments of Himmelmann, Hausmann and Neumann is that the perceptual experience of seeing the gods in bodily form, which is the subject of most votive reliefs, is unrelated to any 'serious', philosophically grounded theology.

The large scale of the gods in votive reliefs has been compared to certain passages in epic poetry, but the comparison is misleading, because the nature of the gods in epic is more like that of the immaterial gods of idealist philosophy than the material gods of votive reliefs. In several passages of epic poetry, a god or goddess is very large. In the Homeric hymns to Demeter and Aphrodite, the goddesses appear to mortals in situations in which they intend for their divinity to be sensed, and here they are described as reaching to the ceiling of a house in height (Hymn. Hom. Dem. 188-89; Hymn. Hom. Aphr. 173-74). ${ }^{10}$ In those passages, however, the size of the gods is motivated by the narrative needs of the immediate poetic context, and not by a theological conviction that the gods are, always and everywhere, as tall as the ceiling of a house. By entering the home of Keleos in disguise, yet on a scale in which 'her head reached to the rafter', Demeter generates immediate deference, which advances her apparent goal of being given the child of Keleos to foster. In the hymn to Aphrodite, the principal point is to mark the difference between the appearance of the goddess now and her appear-

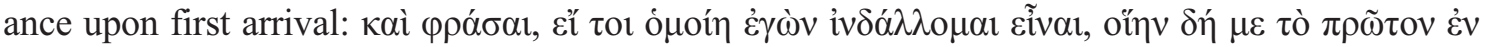

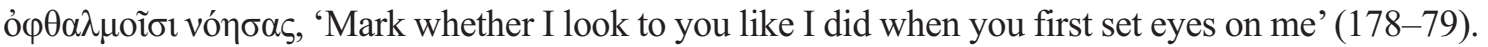

5 Robertson (1975) 1.375.

${ }^{6}$ Himmelmann (1998a) 155 n.45. The observation reflects the much more general and influential argument of Himmelmann (1998b), first published in 1959. Numerous interpretations of the whereabouts and significance of the seated deities in the Parthenon frieze have been suggested, for example Hedreen (2011) 359-60.
7 Hausmann (1960) 57.

${ }^{8}$ Neumann (1979) 78-79. For reservations, see Edelmann (1992) 11.

${ }^{9}$ On this point, see Mikalson (2010) 209-14.

10 See also Hom. Od. 5.216-18. For additional examples, see Richardson (1974) 208. 
More fundamentally, while the gods in epic poetry are occasionally described as taller than ordinary humans, their 'regular' size is impossible to determine, because in epic the gods are essentially polymorphous. ${ }^{11}$ In epic, it is not even the case that anthropomorphic is the default form of the gods, for in the same poem or poetic context (for example, Homeric hymns to Apollo or Dionysos) a god may appear in the form of an aquatic mammal, a beast and a celestial body in quick succession, and it is almost certain that, in Homeric epic, the gods occasionally took the form of small birds. ${ }^{12}$ It is well known that it was believed to be dangerous even to look on a deity in his or her true form, and therefore that gods put on disguises to interact with mortals. ${ }^{13}$ When Hera says to Poseidon and Athena, $\chi \alpha \lambda \varepsilon \pi$ oì $\delta \dot{\varepsilon} \theta \varepsilon o i ̀ ~ \varphi \alpha i ́ v \varepsilon \sigma \theta \alpha \imath$ ċv $\alpha \rho \gamma \varepsilon \tilde{c} \varsigma$, 'it is hard for gods to be shown in their true shape' (Il. 20.130), she seems to imply that the difficulty lies in mortals looking directly at a deity when he or she appears in his or her authentic form, whatever that may be. But it is equally true that it is hard to know what is the true form of a god, for his or her shape is always changing. 'It is hard, O goddess', says Odysseus to Athena, 'for even a man of good understanding to recognize you on meeting, for you take every shape upon you' (Od. 13.312-13, tr. Lattimore (1967), my emphasis). ${ }^{14}$ In short, in epic, large size and anthropomorphic form are occasionally taken by the gods. But in votive reliefs, in contrast to epic poetry, the relatively larger size of the gods compared to mortals is consistent. It appears to be part of their permanent physical makeup, and perceivable by mortals.

Neumann offers an additional explanation of the magnitude of the gods on votive reliefs. He points out that, on the reliefs, the figures of gods and goddesses not infrequently correspond in pose or dress to well-attested free-standing statues, which, during the floruit of votive reliefs, were often over life-size. ${ }^{15}$ For example, the figure of Ares on a relief in the Louvre (fig. 2) has been thought to be modelled on the statue of Ares made by Alkamenes, which Pausanias reports (1.8.4-5) seeing in the Temple of Ares at Athens. ${ }^{16}$ Neumann's interpretation allows a viewer to think that the gods are not really twice as large as mortals, only their free-standing 'cult' statues are, and the mortals are not actually seeing the living material body of a deity but merely an inert sculptural representation of him or her. Charles Edwards has persuasively shown, however, that free-standing statues of various Olympian goddesses served as models for the figures of Nymphs on votive reliefs, not to suggest that Demeter, Persephone or some other goddess are actually Nymphs, but because the images of those great goddesses imported connotations (youth and maturity, innocence and experience) relevant to the characterization of Nymphs, who occupy the cusp between girlhood and womanhood. ${ }^{17}$ In addition, Klöckner has pointed out that interactions between mortals and immortals are handled differently in contemporary vase-painting. ${ }^{18}$ Beginning in the late sixth century BC, vase-painters developed means of explicitly marking the pictorial representation of a divine figure as a depiction of a statue. Sometimes the divine figures are smaller in scale than human figures, sometimes they are dressed in archaizing garments, but most significantly they

11 That the gods in epic are generally understood to be kalos kai megethos is a truism in the scholarship that, I believe, is unsupported by the data. Compare Verdenius (1949) and Gordon (1979) 14.

12 For birds, see Hom. Il. 14.286-91; with Kirk (1990) 239-40. Consider also Il. 7.17-22, 58-60. Generally, see Petridou (2015) 88-89. For the uncanny presence of the gods, see also Burkert (1997).

13 See, Rose (1956) 65-66; Petridou (2015) 32-40; Platt (2016) 165, 170-71.

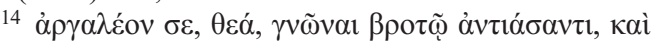

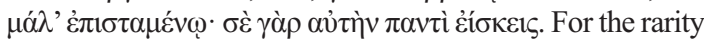
of epiphanic experience in epic, see Turkeltaub (2007) 52.

15 Neumann (1979) 56, 79. On this phenomenon, see Baumer (1997).
16 Paris, Louvre MA 742, said to be from Greece, $c a$. 400-375 BC: Stewart (2016) 593-94, 599, 601. Consider also Athens, Acropolis 2437 plus other fragments; Vikela (2005) 125-26, pl. 20.1, a votive relief on which the figure of Athena looks like the colossal Parthenos statue.

17 Edwards (1985) 41-44. For a critical account of Neuman's approach, see also Tanner (2006) 85-87 and Platt (2011) 31-38, who explore the ambiguity inherent in these statuesque deities. On the limitations of ambiguity as a tool for the interpretation of images of divinity, see Neer (2017). See further reservations about Neuman's approach in Edelmann (1992) 177.

${ }^{18}$ Klöckner (2010) 107-08. For a similar point, see also Lawton (2007) 42. 


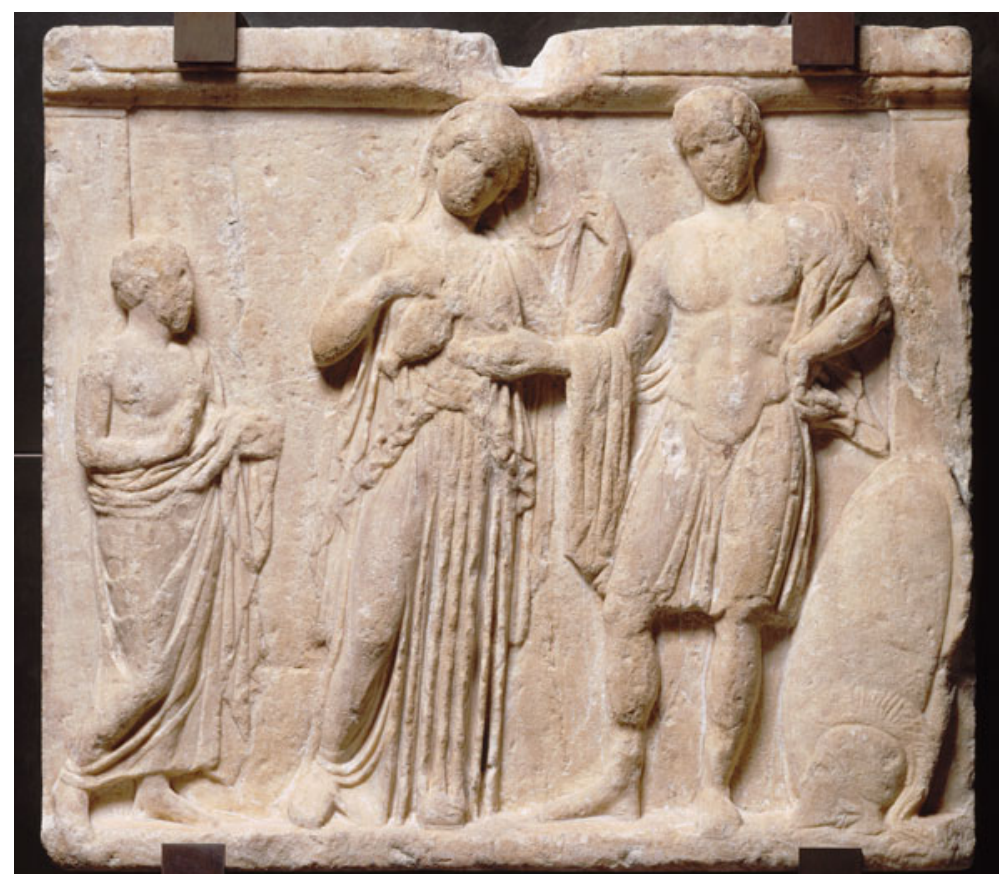

Fig. 2. Attic votive relief to Ares and Aphrodite(?), Paris, Louvre MA 742, ca. 400-375 BC (photograph by Hervé Lewandowski; (C) RMN-Grand Palais/Art Resource, NY).

very often stand on low rectangular steps, which represent the base of a statue. ${ }^{19}$ The images of the gods and goddesses on votive reliefs do correspond in some cases, in pose or dress, to familiar free-standing statues of the deities, but the votive reliefs do not include the standard feature of many vase-paintings, the base of the statue, which ensures that the viewer does not mistake the depicted figure of the deity for the deity him/herself. Without the tell-tale base, the reliefs are open to the interpretation that the depicted donors are looking at the gods 'in person'.

\section{The argument in brief}

The point of departure for my argument is a relatively late document, the De Rerum Natura (or $D R N$ ), written by Lucretius shortly before $55 \mathrm{BC}$. In it, Lucretius offers the following explanation of the human belief in god (DRN 5.1161-82):

What cause has made belief in the gods universal ...? The truth is that even in remote antiquity the minds of mortals were visited in waking life, and still more in sleep, by visions of divine figures of matchless beauty and stupendous stature. To these beings they attributed sensation, because they saw them move their limbs and speak in a majestic manner appropriate to their splendid appearance and ample strength. They gave them immortal life, because their images presented themselves in constant succession and their forms remain unchanged, but above all because they thought that beings endowed with such mighty strength could not easily be overcome by any force. And they regarded them as consummately happy, because fear of death did not trouble any of them and also because in sleep they saw them perform marvellous feats without experiencing any fatigue. ${ }^{20}$

${ }^{19}$ For example, Cerveteri, once Rome, Villa Giulia, 121110; formerly Malibu, Getty Museum, Onesimos, BAPD 13363; LIMC 7, pl. 680, Kassandra I 104; LIMC 8, pl. 400, Ilioupersis 7. See further, Hedreen (2001) 25-
26, Hölscher (2012) 117-18; (2017) 202-23.

${ }^{20}$ Nunc quae causa deum per magnas numina gentis pervulagarit ...

Quippe etenim iam tum divom mortalia saecla 
Lucretius follows the precepts of Epicurus, who, writing around $300 \mathrm{BC}$, affirmed the universal belief in and therefore also the existence of the gods: 'First, think of god as an imperishable and blessed creature, as the common idea of god is in outline, and attach to him nothing alien to imperishability or inappropriate to blessedness ... For there are gods - the knowledge of them is self-evident. But they are not such as the many believe them to be. ${ }^{21}$ In the words of Epicurus that come down to us, the qualities of the gods are blessedness and imperishability, but, Sextus Empiricus attests that size was also an Epicurean criterion (9.43): 'the same reply can be made to Epicurus's belief that the idea of gods arose from dream impressions of human-shaped images. For why should these have given rise to the idea of gods, rather than of outsized men?'22 It appears that Epicurus' theology is similar to that of the fifth-century BC atomist Demokritos, from whom Epicurus derived many aspects of his physics as well. Sextus Empiricus tells us (9.42): "that there should be in the environment gigantic images in human shape and generally all the sorts of things that Democritus tries to imagine is altogether unacceptable'. ${ }^{23}$ But our knowledge of the theology of the atomists is much more fragmentary than our knowledge of Epicurean theory.

In this paper, I focus on one particular criterion of divinity shared by both votive reliefs and texts or testimonia from the atomist and Epicurean writers (who, altogether, for the sake of convenience, I sometimes identify by the imperfect descriptor 'materialists'), namely, the large size of the gods. ${ }^{24}$ The artistic images also bear comparison to the description of the gods in Lucretius and Epicurus in the self-sufficiency, contentment and beauty of the gods, and to the belief that our knowledge of them is based on perceptual experience; but the size or scale of the gods is the most puzzling feature of the theology. I do not believe that the analogy between Classical votive reliefs and materialist theology has been taken seriously in modern scholarship. Nevertheless, examining the two discourses together is valuable because it brings out qualities in each that otherwise go unnoticed. In the reliefs, the scale and relative self-sufficiency of the gods, as well as the visual attentiveness of the mortals, acquire positive value. These features materialize a coherent set of ideas about immortals and mortal religious experience; they cannot be written off as art-historical phenomena devoid of theological significance. The Epicurean/atomist philosophical discourse, for its part, is grounded in the material bodily existence of all mental images and the epistemological value of visual perception: that is, a way of thinking akin to visual, figural, artistic representation.

egregias animo facies vigilante videbant, et magis in somnis mirando corporis auctu. his igitur sensum tribuebant propterea quod membra movere videbantur vocesque superbas mittere pro facie praeclara et viribus amplis. aeternamque dabant vitam, quia semper eorum subpeditabatur facies et forma manebat, et tamen omnino quod tantis viribus auctos non temere ulla vi convinci posse putabant. fortunisque ideo longe praestare putabant, quod mortis timor haud quemquam vexaret eorum, et simul in somnis quia multa et mira videbant efficere et nullum capere ipsos inde laborem.

All translations of $D R N$ after Smith 2001.

${ }^{21}$ In the Ep. Men. (Diog. Laert. 10.123-24); for the Greek text, see below. Philodemos, the first-century BC Epicurean writer, reports that, in book 12 of On Nature, Epicurus says that a conception of imperishable external entities was arrived at by the very first humans. The reference to the earliest humans recalls Lucretius' expression, 'even in remote antiquity', and suggests that Lucretius was familiar with book 12. On this point, see Blickman (1989) 157-58 with n.4; Mackey (forthcoming).

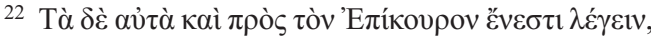

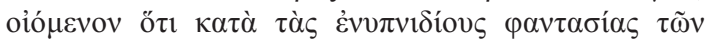

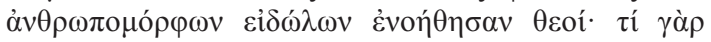

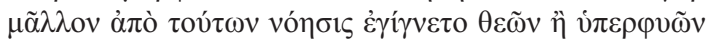
$\dot{\alpha} v \theta \rho \omega ́ \pi \omega v$, tr. after Long and Sedley (1987) 23F.

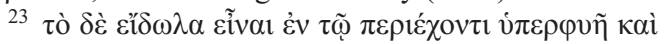

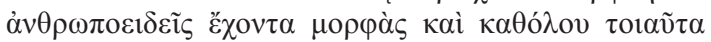

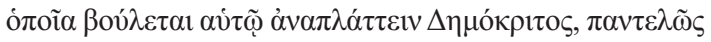
$\dot{\varepsilon} \sigma \tau \grave{~} \delta$

${ }^{24}$ Stoic physics is also materialist, but stoics envisioned god not as anthropomorphic but as fire: see Long and Sedley (1987) 1:277-78. 


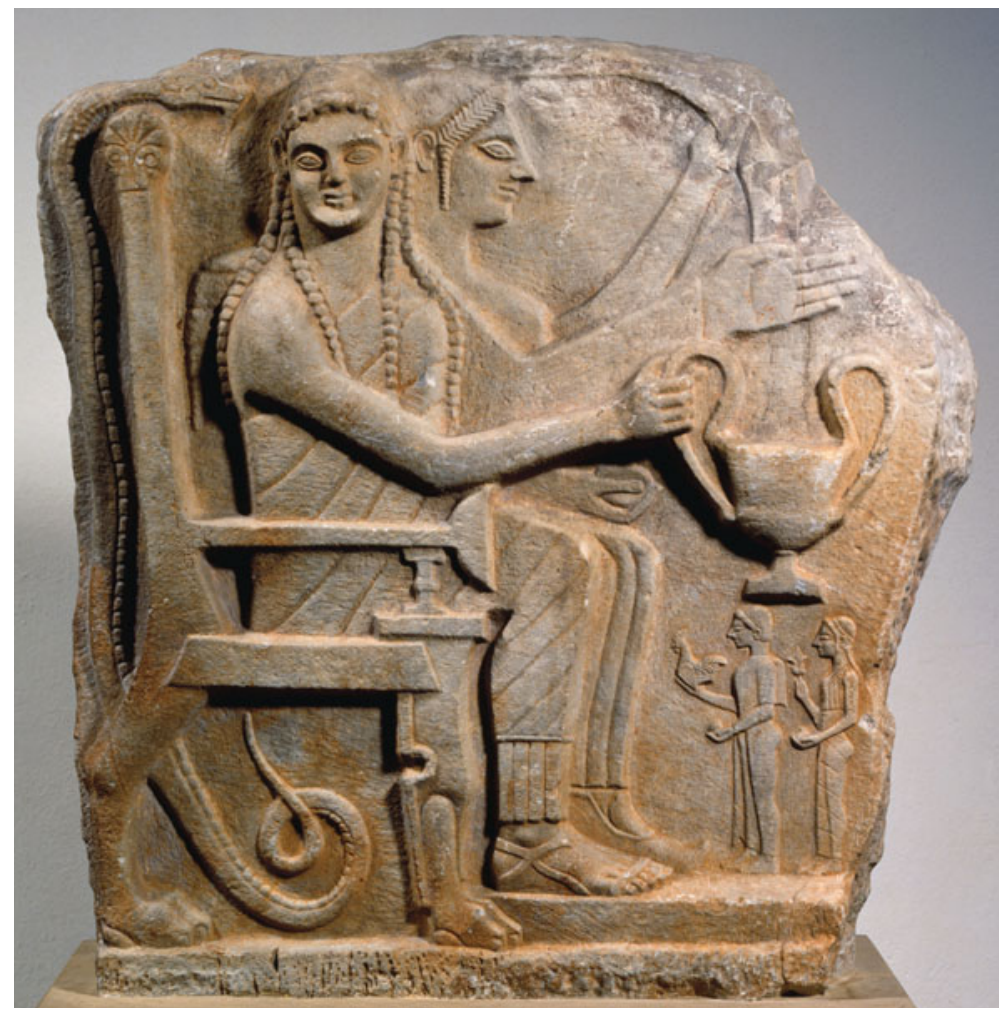

Fig. 3. Lakonian hero relief from Chrysapha, Berlin SK 731, ca. 550 BC (photograph bpk Bildagentur/Antikensammlung, Staatliche Museen, Berlin; photographer Jürgen Liepe/Art Resource, NY).

\section{The magnitude of the gods in votive reliefs: convention or substance?}

One possible interpretation is that the larger scale used to represent gods in votive reliefs is merely a symbolic convention to indicate greater importance and therefore tells the viewer nothing about the material nature of the gods themselves. In that respect, votive reliefs would resemble those funerary or document reliefs in which figures of subsidiary importance, such as servants, are rendered on a smaller scale than the principal figures. ${ }^{25}$ Consider a relief from Chrysapha near Sparta of around $550 \mathrm{BC}$, the earliest surviving example of the juxtaposition of figures of dramatically different scales in Greek sculpture (fig. 3). ${ }^{26}$ A male figure and a female figure are seated on a fancy throne, along the high back of which slithers a bearded snake. Approaching the couple are two adorants bearing gifts. The adorants are tiny figures, barely half the height of the lower legs of the hero and heroine, and fitted into the space available beneath the male figure's large drinking vessel. ${ }^{27}$ Eleanor Guralnick has demonstrated that the Chrysapha and similar Lakonian reliefs are closely related, stylistically, to ancient Egyptian funerary reliefs. The similarities include the basic format of seated figures receiving gifts from persons who approach them as well as the size differential of the figures. In Egyptian funerary art, size differential makes it possible to give visual emphasis to the deceased person and squeeze in more subsidiary figures. The size of figures was

${ }^{25}$ For a survey of the use of variations in scale in Greek art generally, see Rauscher (1971). For its use in the rendering of children, see Lawton (2007) 43.

${ }^{26}$ Berlin SK 731. For the earliest example of such differential in size in painted votive plaques, see Berlin F787, a clay plaque from Penteskouphia, Corinth, LIMC
1, pl. 576, Amphitrite 1. On these plaques, see Simon (1980) 79-83.

27 On this relief, see especially Salapata (2014) 114, 131-32, R1. See also her catalogue number R2, Sparta 3, which, like R1, dates to shortly after $550 \mathrm{BC}$, which is very similar. 


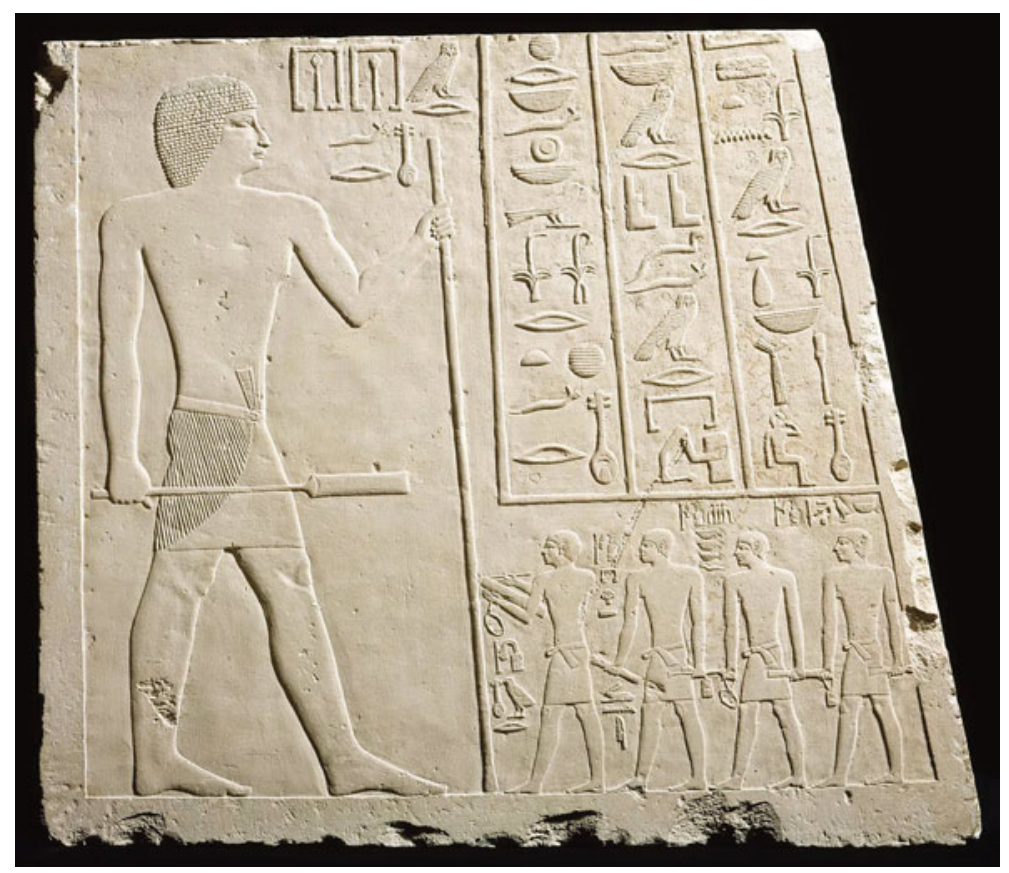

Fig. 4. Funerary relief of Nofer, Egyptian, Boston 07.1002, 25512454 BC (photograph Museum of Fine Arts, Boston).

shaped by the use of multiple registers for the representation of offering bearers as well as texts; often, the height available to the offering bearers appears to have been determined by the space left over for them once the texts had been laid out (for example, fig. 4). ${ }^{28}$ Dramatically different scales were used for figures of many sorts, ranging from gods to Pharaohs to mortals. ${ }^{29}$ In Egyptian art, then, size differential is a compositional and symbolic means of indicating relative importance and does not correspond to the real size of gods, pharaohs, high-ranking officials and lowly servants.

It is not merely the enormity of the disparity between the large figures and the tiny adorants on the Chrysapha relief, but also the identity of the large figures themselves, that invites one to interpret the size difference, in this case, as conventional. It is likely that the seated figures are heroes, rather than god and goddess. The snake, with its chthonic associations, suggests that the Spartan figures ought to be understood in relationship to death, and several important heroes and heroines were worshipped in Sparta, including Agamemnon and Kassandra, and Helen and Menelaos. ${ }^{30}$ For my purposes, the important point is that the couple being honoured in the relief, as hero and heroine, by definition, were mortal human beings before becoming objects of worship. If the viewer of the relief understands the large seated figures to have originally been human and understands the diminutive adorants as well to be human, then the viewer will have a point of reference from which to puzzle out the meaning of the size differential. Heroes and heroines were at one point in time more or less the same size as the adorants; if they are much larger in the relief, then their large size must have symbolic artistic significance, rather than some correspondence to the 'real' height of the hero and heroine after death.

\footnotetext{
${ }^{28}$ Boston, Museum of Fine Arts, 07.1002, relief of Nofer, 2551-2454 BC.

29 Guralnick (1974) 187-88.
}

\footnotetext{
${ }^{30}$ On the question of the identity of the figures being honoured in these reliefs, see Wace (1937) and now the comprehensive study of Salapata (2014).
} 


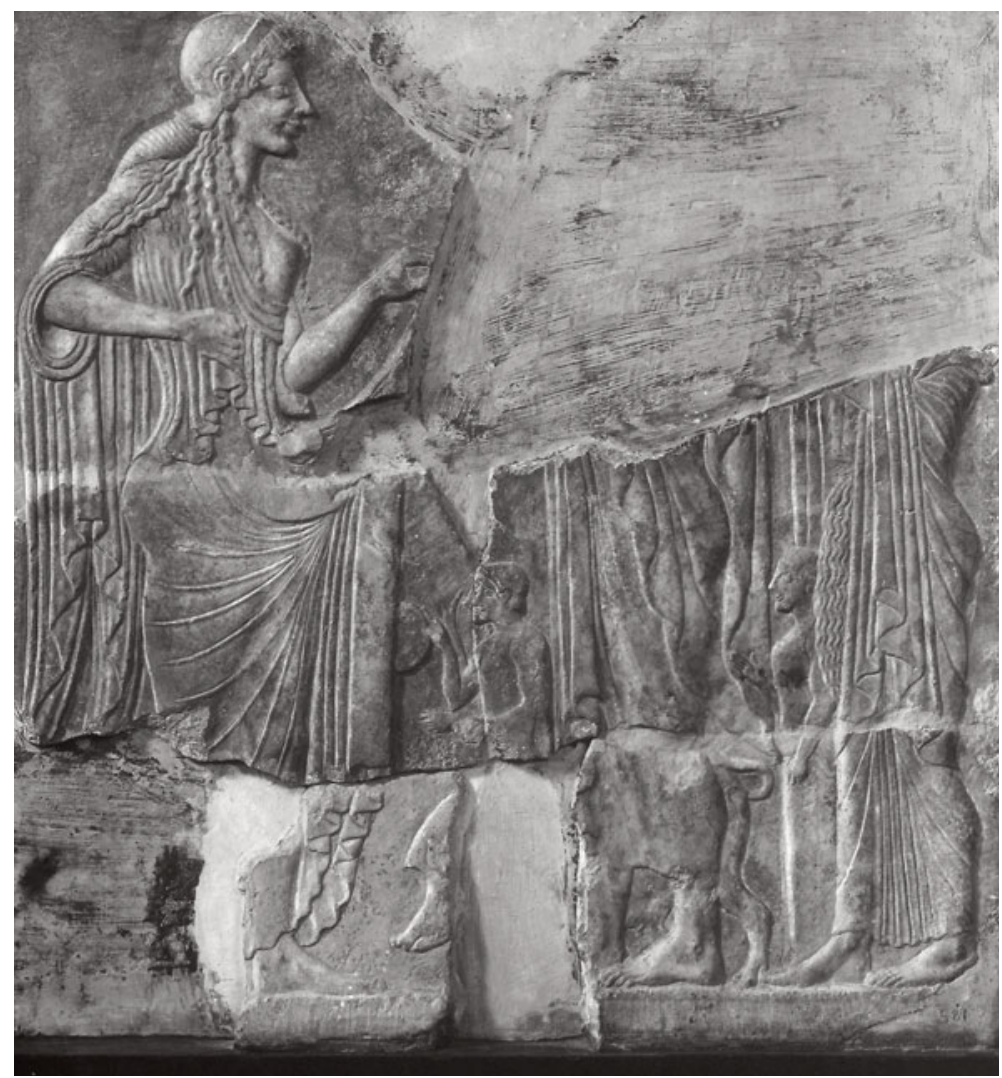

Fig. 5. Pig sacrifice to Athena, Attic votive relief, Athens Akropolis 581, ca. 500-490 BC (photograph Alinari/Art Resource, NY).

By comparison with the Chrysapha relief, a late Archaic votive relief in Athens (fig. 5) is more open, it seems to me, to the interpretation that the super-human size of the figure of worship is part of who she really is. The relief depicts Athena receiving an offering of a pig from a family. The goddess stands holding her helmet as three children and two adults approach. ${ }^{31}$ On the relief in Athens, there is much less difference in scale between the goddess and the donors; compare the height of the hips of all the adult figures. In addition, the figures give the sense that they are aware of each other's presence; the tilt of the goddess' head suggests that she acknowledges the presence of the mortals and the raised hands of the children and, it appears, the adults suggest that the mortals are experiencing something out of the ordinary. ${ }^{32}$ This is the first occurrence in votive reliefs to any deity, from any region of Greece, according to Eugenia Vikela, of what she and other scholars have called the 'dialogic' type of composition familiar from hundreds of later Classical reliefs. ${ }^{33}$ It may be that the difference in size between an adorant and the figure he/she worships originated as a conventional means of distinguishing between mortal and immortal importance. From this point on, however, the Classical votive relief is arguably conceived so as to invite the beholder to wonder if the images of the gods are not genuine perceptions of them, even down to their size. ${ }^{34}$

31 Athens, Akropolis 581, LIMC 2, pl. 762, Athena 587. For the date of the piece, see Evelyn Harrison in Palagia (1995) 493-94.

32 For the positions of the arms of the adults, which are partially lost, see Payne and Young (1936) 48-49.

33 Vikela (2005) 93-94. For the 'dialogical' interpre- tation, see also Berger (1970) 109. For the priority of this relief as the earliest example of the Classical votivesculptural proposition concerning mortal and immortal interactions, see Simon (1977); Neumann (1979) 38; Comella (2002) 20.

34 In this respect, I disagree with Rauscher (1971) 


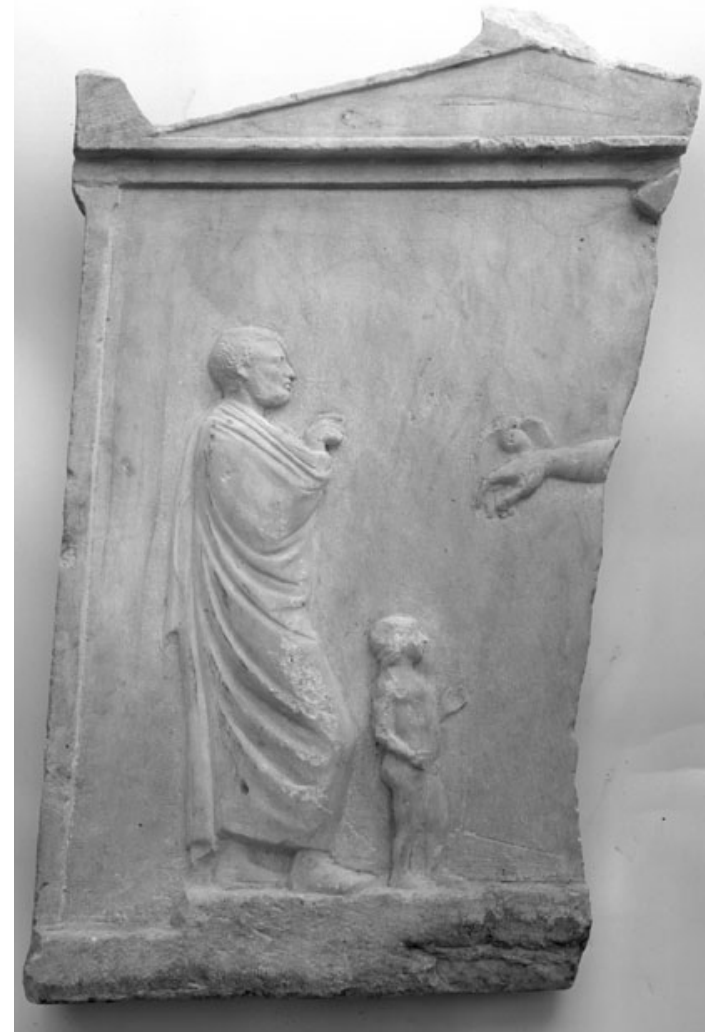

Fig. 6. Father and son in the presence of Athena, Attic votive relief, Athens NM 3030, fourth century BC (photograph D-DAI-ATHAkropolis 2301; photographer Gösta Hellner).

\section{Gaze and gesture}

The formal or compositional invitation to interpret the images of the gods as percepts rests on several characteristics of the reliefs. One is the unambiguous expression of visual interest on the part of the mortal figures. In the great majority of reliefs, the worshipper or dedicant raises one hand up, palm facing the divine, and, at the same time, looks directly at the deity, in an unambiguous acknowledgement of the visual presence of the supernatural being; the donor sees the god. For example, on a fragmentary late Classical or Hellenistic relief in Athens (fig. 6), a father and a son approach the goddess Athena. All that remains of the goddess is the tip of her helmet and her right arm, on which alights an owl. She extends her hand, it seems, in the direction of her worshippers - but does not make physical contact with them. Both the father and the son look upwards toward the (lost) face of the over-life-size goddess, and both raise one hand, the father with one finger curled in extension. ${ }^{35}$ The possibility that the mortals and immortal, because of the disparity in scale, are not to be understood as part of the same spatiotemporal continuum is belied by the gesture. The two recurrent pictorial features, scale and gesture, go hand in hand. In addition, in Classical votive reliefs there is virtually always a gap between the gods and the mortals, so that the interaction between the two groups is always visual, across some distance of space, and not tactile. Exceptions to this rule occur

112, who argues that the Spartan hero reliefs were the prototype for the Classical votive relief, in the sense that the difference in scale of the figures had the same meaning in both genres or types.
35 Athens, NM 3030; Comella (2002) 101, fig. 93, no. 42; Shapiro (2003) 97-98. Compare Lawton (2007) 48: 'an awestruck gesture'? 


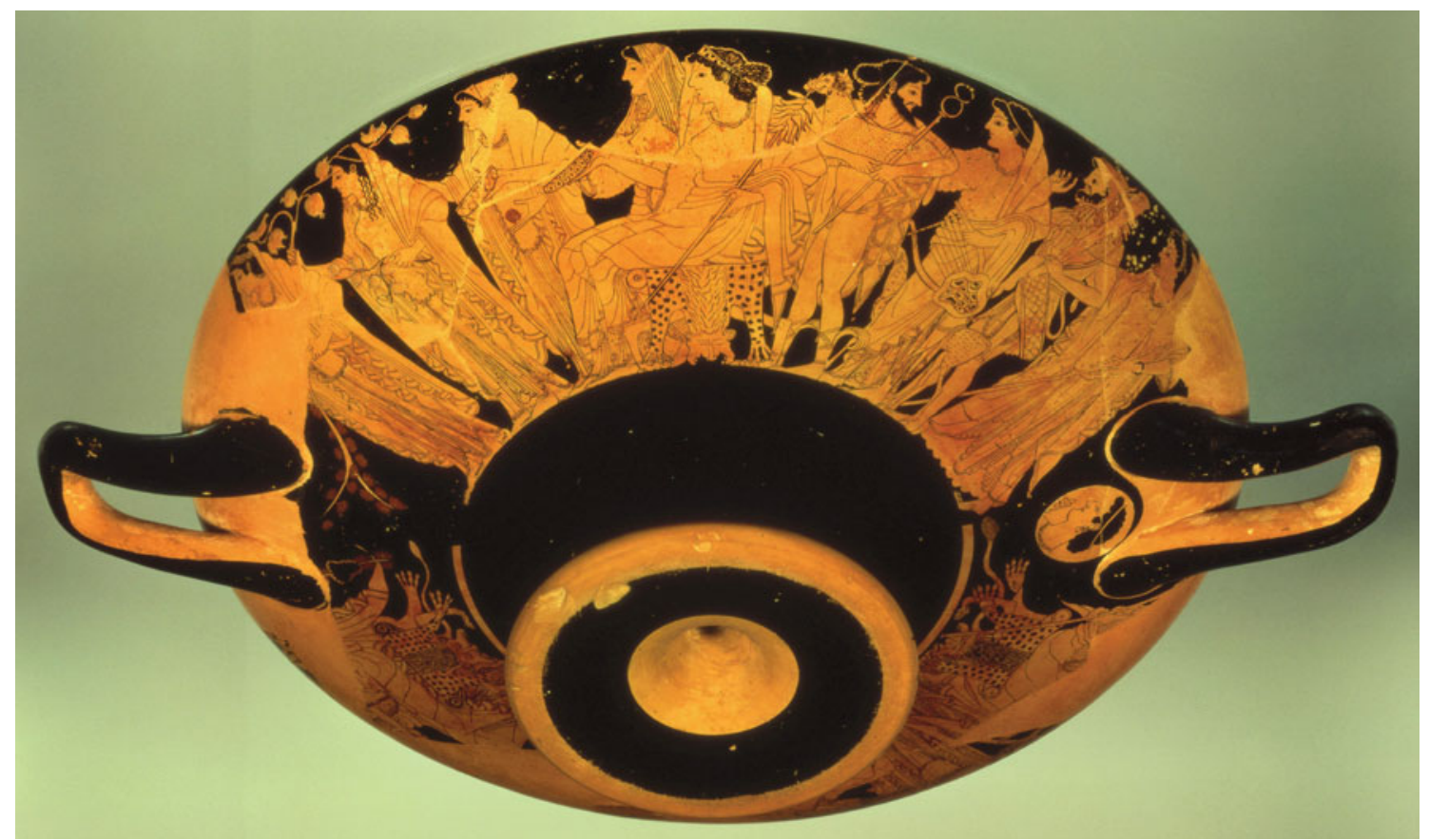

Fig. 7. Sosias cup, Herakles arrives on Olympos, Attic red-figure cup, Berlin F2278, BAPD 200108, ca. 500 BC (photograph bpk Bildagentur/Antikensammlung, Staaliche Museen, Berlin; photographer Johannes Laurentius/Art Resource, NY).

only, so far as I know, in a few votive reliefs dedicated to the healing gods, where the gods are occasionally depicted laying their hands on the votary, who was or is a patient. ${ }^{36}$

About the gesture of the raised hand with palm open or one finger curled, Alan Shapiro notes that it looks as if the donor is trying to attract the god's attention. ${ }^{37}$ What I wish to emphasize is the visual nature of the connection signalled by the gesture. In this respect, the gesture made by Herakles on the Sosias cup of around $500 \mathrm{BC}$ (fig. 7) is illuminating, despite the differences in the underlying narrative situations and lack of size difference. The cup depicts the arrival of the hero at the home of the Olympian gods, who are almost all seated and all looking toward Herakles' father Zeus. The hero raises his right hand up, palm forward, fingers curled, more or less as the votary does on the relief. There is an accompanying inscription on the vase, and the words uttered by Herakles, as he makes the gesture, (Z)eu phile, 'dear Zeus', are suggestive. While it is possible to take the words to be a loud verbal greeting from son to father, that interpretation is discouraged by the distance between the two figures: Zeus is located almost as far away from Herakles as possible compositionally, on the other side of the cup; how could he hear his son? The words make better sense as the words that Herakles says to himself upon his arrival on Olympos, when he is allowed for the first time to actually see his father Zeus. ${ }^{38}$ The words help us to understand what mental experience the gesture signifies.

36 Examples include the relief from Oropos dedicated to Amphiaraos, Athens, NM 3369, LIMC 1, pl. 564, Amphiaraos 63, or the relief from the Asklepieion in Piraeus, Piraeus Archaeological Museum, 405, LIMC 2, p. 876, Asklepios 105; I thank a reviewer for the latter example. On the reliefs to the healing gods, Edelmann (1992) 178 points out that the overall impression is still one of distance between mortals and immortals.

37 Shapiro (2014) 64.

38 Berlin F2278, ARV 21, BAPD 200108. Neumann
(1965) 82, interprets Herakles' gesture, as well as the gesture on votive reliefs, as one of worship. Worship, however, seems at odds to me with the underlying narrative situation, in which it is Herakles who is being honoured. For other interpretations of the gesture, see Himmelmann (1998a) 139; Simon (2016) 134-35. Consider also the gesture of Theseus in two depictions of the hero responding to the presence of the immortals on the cup in New York by the Briseis Painter, New York 53.11.4, ARV 406,7, BAPD 204406. 


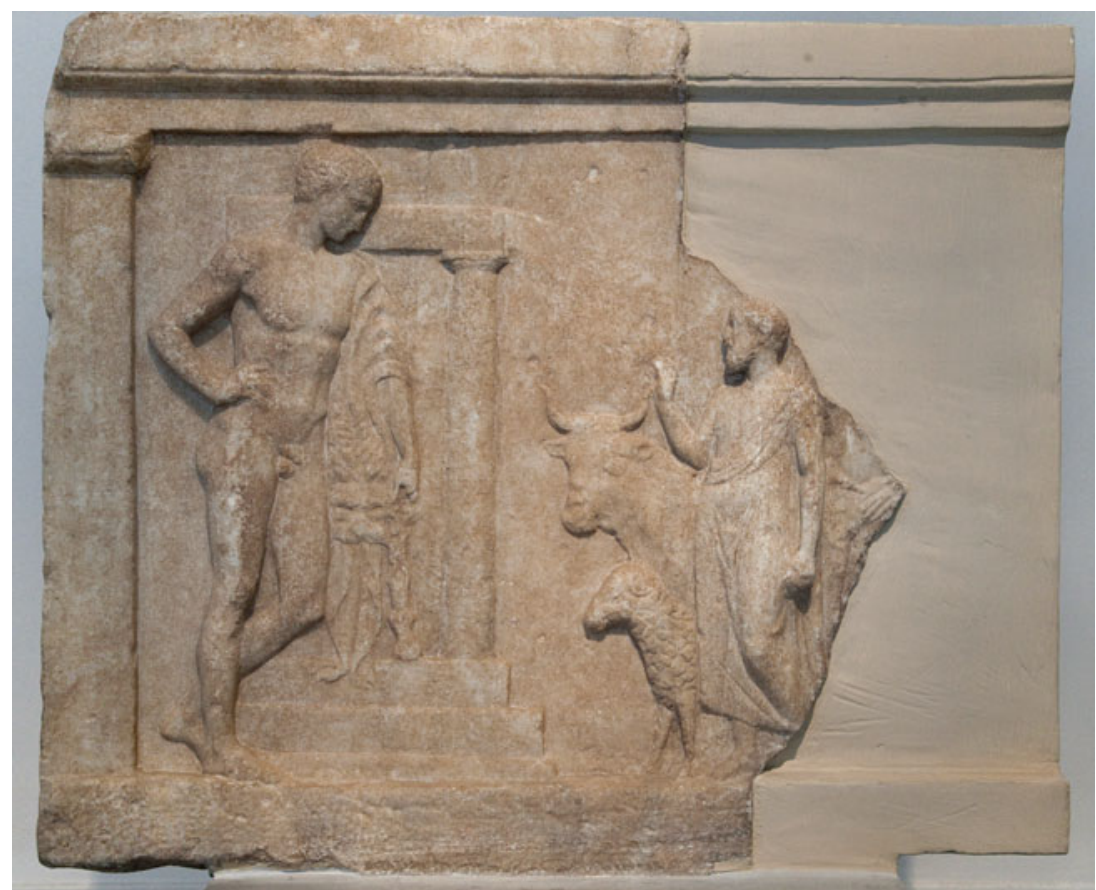

Fig. 8. Herakles and worshipper, Attic votive refief, Athens NM 1404, ca. $400 \mathrm{BC}$ (photograph (C) Vanni Archive/Art Resource, NY).

In the votive reliefs, the presence of the gods visually to mortal worshippers is also underscored, formally and compositionally, by the fact that the gods often acknowledge the presence of the mortals. In many cases, they indicate an awareness of the presence of worshippers through the direction of their gaze (for example, fig. 1). More rarely, they do so with a movement of a hand (fig. 6). Occasionally they do not acknowledge the presence of the mortals at all ${ }^{39}$ In any case, three points are important: first, in these reliefs, the gods are not inert material bodies, like statues in a temple, but living beings capable of response; second, the intensity of the mortal response is absent from the response of the gods. ${ }^{40}$ Mortals turn to the gods in the hope that the gods will supply something that mortals need; but the reliefs suggest that gods do not need anything from mortals. ${ }^{41}$ The third characteristic feature of the response of the gods and goddesses to the presence of mortal worshippers in votive reliefs is a casualness that belies the idea that the deities have come to their sanctuaries for the depicted event. In the reliefs, it is suggested that the gods and goddesses are at home, and doing whatever it is that they always do. For example, on a relief depicting Herakles of around $400 \mathrm{BC}$ (fig. 8), the direction of the god's gaze suggests a passing awareness of the arrival of the devotee, who raises one hand in a greeting to the hero. ${ }^{42}$ Yet the hero's pose does not suggest that he has just arrived at the shrine depicted in the background in answer to his devotee's prayer. The hero leans on his club, with his left arm at rest; his right hand rests on his hip, akimbo; his left leg is bent and resting. This is the body language of a person with nowhere to go and nothing to do. It is as if he stands there, all the time, resting from a lifetime of labour, whether or not anyone is present to

39 For example, Ny Carlsberg 197, carved perhaps in Argos around 420 BC; Neumann (1979) pl. 24a: two gods and two goddesses are oriented so that the god at each end encloses the goddesses in the middle in a tight conversational group, which excludes the diminutive donor, who is squeezed into the composition on the far left.
40 A perceptive analysis in Neumann (1979) 53.

${ }^{41}$ In this respect, the Classical votive reliefs both do and do not exemplify the formulation of religious visuality in an influential account by Elsner (2007) 24 .

42 Athens, NM 1404; Kaltsas (2002) no. 266. On votive reliefs of this type, see Klöckner (2015). 


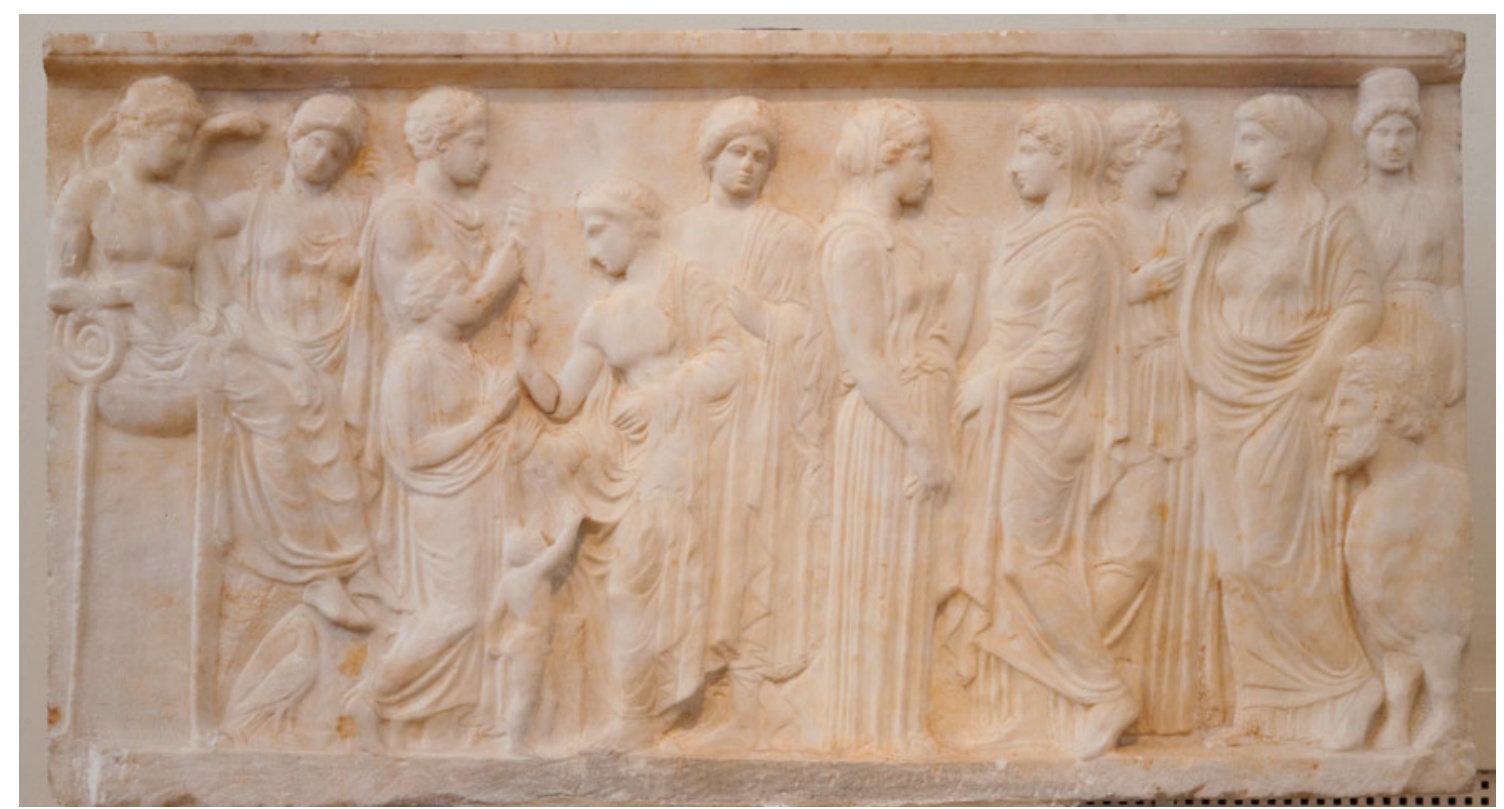

Fig. 9. Xenokrateia relief, Attic votive relief, Athens NM 2756, ca. 405-390 BC (photograph (C) Vanni Archive/Art Resource, NY).

witness. On a late-fifth-century relief from a shrine of the Charites on Kos, a diminutive male worshipper, identified in writing as Peithanor, gazes in wonder at the three Graces identified in the dedicatory inscription, who seem to pay him no attention as they dance hand in hand. ${ }^{43}$ Dancing is what the Graces do best, and one can imagine that they have been dancing like this for a long time. ${ }^{44}$

The most complex of all extant votive reliefs is the beautiful, late fifth-century BC relief dedicated by Xenokrateia (fig. 9). Thirteen figures in all crowd together, two of whom appear to be mortal and $11 \mathrm{immortal}$. An accompanying inscription tells us that Xenokrateia dedicated the relief to Kephissos 'and to the gods who share the altar'. A second inscription from the site lists a dozen gods worshipped there, some of whom can be plausibly recognized on the relief (Acheloos, Artemis, Hermes, the Nymphs). ${ }^{45}$ Overlapping and in front of a figure who may represent Hermes, but of no visual interest to him, and only a little over half as tall as the surrounding divinities, is a female figure. Her diminutive scale indicates that she is Xenokrateia herself, the dedicant of the relief. A very small boy stands in front of her, presumably her son, Xeniades, named in the text. Xenokrateia reaches with both hands, and the boy raises his right hand, toward a male figure who leans toward and seems to be speaking to them, raising his right hand in a gesture. He is often identified as the river god Kephisos. Unlike the Classical votives considered so far, the mortal figures are not relegated to one edge of the relief or the other and the action does not unfold across the plane, with the mortals explicitly separated spatially from the immortals. Here, the mortals are surrounded by the gods, who nevertheless convey a sense of otherworldliness and self-absorption through lack of eye contact. The relief beautifully expresses the idea that the divine is all around us, visible on occasion because materially embodied, yet not part of our everyday lives.

${ }^{43}$ Kos, LIMC 3, pl. 153, Charis, Charites 24; discussed by Van Straten (1976) 1-2.

${ }^{44}$ I understand the Nymph reliefs somewhat differently from Klöckner (2010) 115, who interprets the movement of Nymphs as a sign of their arrival or epiphany. It seems reasonable to think that the votive reliefs of dancing Nymphs or Graces record the experi- ence of an epiphany, but the movement of the goddesses, I believe, is perpetual, part of their being.

45 Athens, NM 2756; Edwards (1985) 310-38, a highly detailed commentary; Edwards dates the relief to 405-390 BC. Apollo is included in the relief but not present in the inscription. For recent bibliography, see Hölscher (2017) 192. 


\section{Size versus scale}

Size is, as R.L. Gordon once pointed out, a matter of point of view. To say that a god is large is only meaningful within a comparative framework. For example, Strabo notes that the figure of Zeus in the gold-and-ivory statue created by Pheidias did not fit inside of the temple of Zeus at Olympia, in the sense that, if the figure stood up, it would breath through the ceiling. The statue was very large compared to a human, but it acquired additional semantic value in comparison to the interior space of the building. By not 'fitting' the building created for him, the god transcends human expectations. Gordon calls attention to Pausanias' comment (10.37.1) about a statue of Artemis by Praxiteles, that 'in size, the statue is larger than the largest woman'. Human form connotes a certain size range; to make an anthropomorphic deity larger than that range means that the god both is and is not 'human'. ${ }^{46}$ The point is that the size of a sculptural image becomes meaningful when some other significant comparanda provides a scale for comparison. As Jennifer Roberts has pointed out, 'scale, quite simply, is difficult to see'. The human eye resizes virtually every object of vision, in order to project it on to the retinae. Thus we can never have a primary visual experience of size. The only direct sensations of size are tactile; in order to translate tactile knowledge into visual experience it is necessary to rely on perceptual cues ${ }^{47}$ Those cues are absent in the case of free-standing statues of gods without any frame. Free-standing statues of mortals can be more or less objectively said to be over or under 'life-size', because all humans fall within a fairly limited range of sizes. Not so a free-standing statue of a god. The $12 \mathrm{~m}$-Promachos and $0.6 \mathrm{~m}$-mourning Athena presumably depict the same entity, but the precise size of the goddess herself is unknown and therefore one cannot say which of the two statues is closer to the real goddess in size. ${ }^{48}$

The Classical votive relief stands apart from the problem presented by the free-standing statue of a deity with respect to the question of the size of the gods. The votive relief always includes a perceptual cue, in the form of the representation of one or more human worshippers, which makes it possible to say, in a meaningful way, that gods are always marginally larger in size than mortal human beings. Because there are many hundreds of votive representations, from many different artists, workshops, periods and regional styles, votive reliefs make it is possible to speak of the size of the gods with a certain precision, to generalize about the size of the gods. Within this particular sculptural genre or discourse, the form and size of the gods can be spoken of with greater specificity than in the case of, say, epic poetry. The manner in which the form and size of the gods is spoken of in atomist or Epicurean philosophy turns out to be the same.

\section{Epicurus and Demokritos on our knowledge of the gods}

The possibility of accounting for the existence of god as well as human knowledge of it within a materialist theory of reality appears to have been seriously entertained by the atomist Demokritos in the fifth century BC. Our knowledge of his theology is limited, however, to less than objective accounts such as the writing of Sextus Empiricus. In addition to the passage quoted earlier, Sextus elsewhere elaborates:

Demokritos says that certain images [eidōla] approach people ... These are large and of greater size than normal, and hard to destroy but not indestructible ... It is on this basis that the ancients, having a representation [phantasia] of these very images, came to suppose that there is a god, given that no other god exists that has an indestructible nature besides these. ${ }^{49}$

46 Gordon (1979) 13-14. On the chryselephantine statue of Zeus, see also Steiner (2001) 95-104, Porter (2010) 407; Osborne (2011) 203.

${ }^{47}$ Roberts (2016). On scale, see also Foxhall and Barfoed (2015).

${ }^{48}$ For the height of the Promachos statue, see Dinsmoor (1921). The mourning Athena: Athens, Acrop- olis 695, LIMC 2, pl. 765, Athena 625. See also Gaifman (2016) on the early fourth-century South Italian vase fragments in Copenhapen, inv. 2579, in which figures of Apollo appear in the same image in two different sizes.

49 Tr. after D154 LM (Sext. Emp. 9.19): $\Delta \eta \mu$ кокло

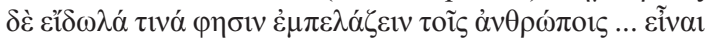

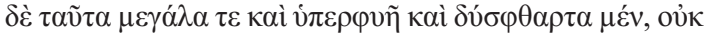


The important point in this passage is that belief in the existence of super-human-size gods is founded upon the perception or mental experience of phantasiai, 'images', of them. ${ }^{50}$

Lucretius' immediate source was Epicurus of the late fourth and early third centuries BC, who followed Demokritos to an extent still uncertain. ${ }^{51}$ As quoted in the introduction, in the Letter to Menoeceus (Diog. Laert. 10.123-24), we have, it is said, the words of Epicurus himself: 'first, think of god as an imperishable and blessed creature, as the common idea of god is in outline, and attach to him nothing alien to imperishability or inappropriate to blessedness ... For there are gods - the knowledge of them is self-evident. But they are not such as the many believe them to be. ${ }^{52}$ The key ideas here, that knowledge of god is universal and self-evident, and that the gods are blissful and imperishable, reappear in a long description of Epicurean theology in Cicero's De natura deorum (1.17-18 [43-46]). The existence of gods 'rests on the unanimous and abiding consensus of mankind; their existence is therefore a necessary inference, since we possess an instinctive or rather an innate concept of them; but a belief which all men by nature share must necessarily be true; therefore it must be admitted that the gods exist' (1.17 [44], tr. Rackham). ${ }^{53}$

Cicero adds that, in Epicurean thought, the gods have bodies that are human in shape, 'for in what other form do they ever appear to a person, awake or asleep?' (1.18 [46]). Philodemos confirms the Epicurean belief in the anthropomorphic form of the gods, in his critique of Stoic theology: '[those Stoics] have not even thought fit to leave us those gods of the form like that in which they are universally worshipped ... For they credit no gods in the shape of humans, but only airs and breezes and aethers. ${ }^{54}$ Epicureans departed from the atomists, however, in thinking that gods are not merely hard to destroy but indestructible, which challenged their own principle that nothing lasts forever.

The materialist claim that the existence of gods is proved by human perceptual experience, which is similar to the visual claim that, I believe, is being made in the votive reliefs, depends upon atomist and Epicurean theories of perception and knowledge. They were essentially empiricist in the sense that, if an image or idea exists in the mind, it must also exist in the world: 'Leucippus, Democritus, and Epicurus say that perception and thought occur when eidola come from outside; neither of these happens to anyone without the impact of an eidōon. ${ }^{55}$ Lucretius explains Epicurean epistemology in detail in book 4 of the $D R N(4.26-34)$ : 'what we term images of things ... are sort of membranes stripped from the surfaces of objects and float this way and that through the air. It is these that visit us when we are awake or asleep. ${ }^{56}$ Not merely visual perception but

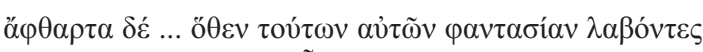

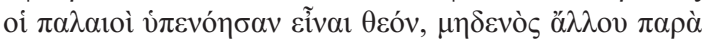

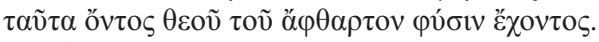

50 This testimonium raises special interpretive difficulties, which I do not pursue. See further Ferwenda (1972) 346; Clay (1980) 353-54 and passim.

${ }^{51}$ Cic. Nat. D. 1.26 [73]: 'what is there in Epicurus' natural history that is not from Democritus?'

52 Text and tr. after Long and Sedley (1987) 23B:

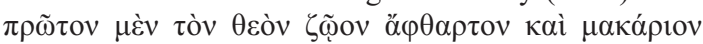

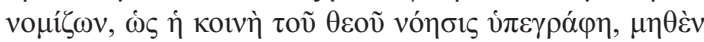

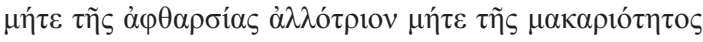

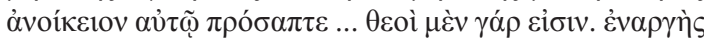

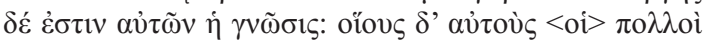

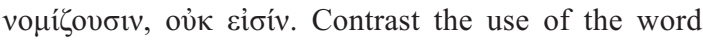
enargēs here with its use by Hera in Hom. Il. 20.130, quoted above.

${ }^{53}$ Cum enim non instituto aliquo aut more aut lege sit opinio constituta maneatque ad unum omnium firma consensio, intellegi necesse est esse deos, quoniam insitas eorum vel potius innatas cognitiones habemus; de quo autem omnium natura consentit, id verum esse necesse est; esse igitur deos confitendum est. For a close reading of the passage of Cicero, with a focus on the meaning of the expression 'or rather an innate concept', see Sedley (2011).

${ }^{54}$ On piety, columns 362-63 = PHerc. 1428 col. 10

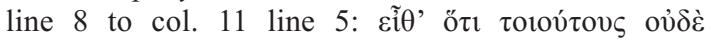

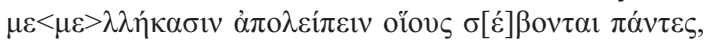

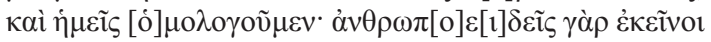

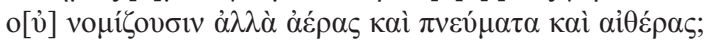
text and tr. after Obbink (2001) 209-10.

55 Stob. 1.50.12=Aët. 4.8.10, tr. Taylor (1999) $115 \mathrm{~b}$ See also the testimonia collected under Taylor (1999) test. $119 \mathrm{a}=$ Demokritos D145 LM.

56 esse ea quae rerum simulacra vocamus; quae, quasi membranae summo de corpore rerum dereptae, volitant ultroque citroque per auras, atque eadem nobis vigilantibus obvia mentes terrificant atque in somnis. 
also mental images are dependent on external effluences according to the Epicureans: '[some membranes] are far finer in texture than the images that occupy our eyes and provoke sight, since they pass through the interstices of the body, stir the subtle substance of the mind within, and so provoke its sensation' (DRN 4.728-32).

In this account, Lucretius appears to have followed closely the ideas of Epicurus, which are summarized in the Letter to Herodotos: "there is a continuous flow [of atoms] from the surface of bodies ... which preserves for a long time the positioning and arrangement which the atoms had in the solid body ... it is on the impingement of something from the outside that we see and think of shapes. ${ }^{57}$ Demokritos' theory of perception is similar, in part, to the Epicurean: every object emits thin films of atoms, or effluences, faithful in shape to the original object. Before it strikes a human eye, however, the effluence compresses the air in front of it, causing an 'air impression', 'like wax that is squeezed and pressed', as Theophrastos put it, a metaphor drawn from the world of artistic image-making; retaining the shape of the original effluence, the air impression then strikes the eye. ${ }^{8}$ The Epicureans adopted the idea of effluences from Demokritos, but abandoned the intermediary air impression. ${ }^{59}$ As David Sedley observes, the words used in this tradition to describe an effluence capture the idea 'of a painted or sculpted image preserving the surface features of its subject'. ${ }^{60}$

\section{The nature of the gods in the materialist tradition}

The materialist philosophers grounded the existence of god in human perceptual experience, not metaphysical speculation. Perhaps as a result, their accounts about the nature of the gods are not perfectly clear. Ambiguity can be sensed even within the single poem of Lucretius: on the one hand, he says: '[one] notion that you cannot possibly accept is that the holy habitations of the gods are located in any part of the world. In fact, the nature of the gods is so tenuous, and so far removed from our senses, that it is scarcely perceptible even to the mind' (5.146-49). ${ }^{61}$ Elsewhere, however, he speaks, quite unambiguously, of 'the images that emanate from their sacred bodies and enter human minds with news of divine beauty' $(6.76-78){ }^{62}$

Concerning Demokritos, the available evidence, skimpy as it is, attributes two different understandings of the nature of the gods to his theology. One idea is that eidōla or 'images' of the gods are emitted by materially embodied entities; this is what one would expect, since perceptions, in his system, as we have seen, always correspond to some object in the world. ${ }^{63}$ There is, however, another, fairly well-attested understanding of the theology of Demokritos, namely, that the gods

57 Ep. Hdt. (Diog. Laert. 10.48-53), text and tr. after

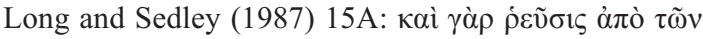

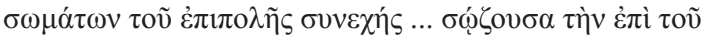

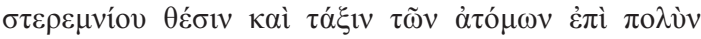

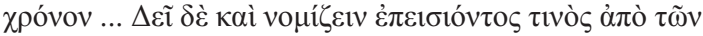
$\check{\varepsilon} \xi \omega \theta \varepsilon v$ ó $\tilde{\alpha} \nu \dot{\eta} \mu \tilde{\alpha} \varsigma \kappa \alpha i ̀ ~ \delta 1 \alpha v o \varepsilon \tilde{\tau} \sigma \theta \alpha$. On the relationship between the theory of visual perception in Lucretius and that in Epicurus, see Bailey (1947) 3.1180-81.

58 Theophr. Sens. 50, in Taylor (1999) test. $113=$ Demokritos D147 LM. See also D146 LM = B123 DK: 'deikelon: ... in Democritus, an efflux that is similar in species to things'. Some scholars believe that Demokritos combines an intromissionist theory with an extramissionist account of visual rays emerging from the eye. In favour is Rudolph (2016) 50; opposed is Nightingale (2016) 55-56. For the terminology, see Squire (2016) 16. The theory that all objects in the world emit effluences appears to have originated with Demokritos' predecessor Empedokles: see Empedokles fragment D208 LM = D89 DK. On Empedokles' theory of vision, see Sedley (1992) 20-26.

59 See Burkert (1977) 103-06.

60 Sedley (1998) 39.

61 Illud item non est ut possis credere, sedes esse deum sanctas in mundi partibus ullis. tenuis enim natura deum longeque remota sensibus ab nostris animi vix mente videtur.

62 ... de corpore quae sancto simulacra feruntur in mentes hominum divinae nuntia formae, suscipere haec animi tranquilla pace valebis.

On the suggestive interpretation of these lines in relation to ancient artistic representations of gods of Eckerman (2019), see below.

63 Ferwenda (1972) 347. 
are nothing but eidōla. ${ }^{64}$ This idea has allowed writers both ancient and modern to conclude, rightly or wrongly, that, for Demokritos, gods are nothing more than the content of human fantasy. ${ }^{65}$

The nature of god in the thought of Epicurus is even more controversial. One interpretation, the 'realist' view, understands Epicurus to have thought that the gods are material beings of whom we have knowledge thanks to the effluences emitted by their bodies. The other interpretation, the 'idealist' view, takes Epicurus to mean that gods are a projection of the human ideal of the perfect life. ${ }^{66}$ The idealist interpretation, as revived by Anthony Long and David Sedley, places considerable weight on the description of Epicurean theology in the De natura deorum. First, Cicero uses the word 'innate' to describe the nature of human knowledge of the gods: 'we possess implanted, or rather innate (vel potius innatas) cognitions of them' (1.17 [44]). Sedley suggests that Cicero's paraphrase, 'or rather innate', more accurately expresses what Epicurus really meant. ${ }^{67}$ Second, Cicero claims that Epicurus believed the gods to be discernible only by the mind and not by sensation, which would seem to contradict the Epicurean commitment to empiricism. The claim is made in a difficult passage of the text (1.19 [49]):

[Epicurus] teaches that the force and nature of the gods is of such a kind that it is, primarily, viewed not by sensation but by the mind, possessing neither the kind of solidity nor the numerical distinctness of those things because of their concreteness he calls steremnia or 'solid'; but that we apprehend images by their similarity and by a process of transition, since an endless series of extremely similar images arise from the countless atoms and flows to the gods. ${ }^{68}$

In this passage, the process by which we apprehend images of the gods is a special one called 'similarity and transition'. ${ }^{69}$ This seemingly opaque formulation has been explained in several different ways. One is that it is a translation of kath' homoioteta metabasis, 'transition by similarity', a process defined by Philodemos. In his writing, the expression describes a process of comparing instances of perception, noting similarities and differences, and arriving at a conception based on a recognition of recurring patterns. ${ }^{70}$ One might compare a passage of Sextus Empiricus:

64 The latter idea is attested in a couple of different testimonia: see Taylor (1999) 211-12; Mackey (forthcoming). Cicero attributes both views to Demokritos: '[he] sometimes counts among the gods their images [i.e., eidōla] and wanderings, sometimes the nature that sends forth and emits images' (Nat. D. 1.12 [29] = Demokritos D209a LM). See also Hermippos, 'the eidola themselves they call [sc. daimonas]' (De astrol. 1.16.122, text in Mackey (fothcoming)).

65 See Taylor (1999) 211 n.45, with references to scholars who hold that Demokritos did not believe in the independent existence of the gods. Taylor himself, however, argues that, in Demokritos, eidola of the gods are not psychological in origin but part of the objective world.

${ }^{66}$ For the terms 'idealist' and 'realist', see Sedley (2011) 29. For those who favour an idealist view, see Long and Sedley (1987) 145, 149; Obbink (2001) 184; O'Keefe (2014) 155-59; Eckerman (2019). The argument against the Long/Sedley view is advanced by Mansfield (1993); Babut (2005); Konstan (2011). A nuanced position between the two is articulated by Purinton (2001)
${ }^{67}$ Sedley (2011). The meaning of the word innatas in this context, however, is not above suspicion: see Konstan (2011) 66-68.

68 Tr. Long and Sedley (1987) 142-43, no. 23E: docet eam esse vim et naturam deorum, ut primum non sensu sed mente cernatur, nec soliditate quadam nec ad numerum, ut ea quae ille propter firmitatem $\sigma \tau \varepsilon \rho \varepsilon \dot{\mu} \mu \nu \imath \alpha$ appellat, sed imaginibus similitudine et transitione perceptis, cum infinita simillumarum imaginum species ex innumerabilibus individuis existat et ad deos adfluat. The Epicurean disciple Diogenes of Oenoanda (= Demokritos fr. 211 Taylor) describes the gods as 'being constructed of atoms which are fine in texture and conceivable only in thought'. He seems to suggest that it is possible for the gods to be discernable only by the mind yet still be material beings.

${ }^{69}$ This is not the only obscure expression in this passage. For ad numerum, 'numerical distinctness', see Purinton (2001) 183; for the difficulty with ad deos, see Mansfield (1993) 196.

70 On the expression, its use in Philodemos and relevance for understanding Cicero, see Asmis (2009) 8889. 
[the Epicureans say] that the idea of god's existence originated from appearances in dreams, or from the world's phenomena, but that the idea of god's being everlasting and imperishable and perfect in happiness arose through a process of transition (or metabasis) from men. For just as we acquired the idea of a Cyclops ... by enlarging the common man ... so too we have started with the idea of a happy man ... then intensified those features into the idea of god. ${ }^{71}$

Long and Sedley have developed that idea into their controversial claim that 'gods, like giants, are thought-constructs'. ${ }^{72}$ More recently, however, Jeffrey Purinton has argued persuasively that, in this passage of Cicero, the word transitio is a translation of the Greek technical term, huperbasis, as in the expression, huperbasis tōn metaxu, 'transcendence of the intervening gaps', which also occurs in Philodemos. The 'endless series of extremely similar images', which 'arise from the countless atoms', are converted in humans minds, by eliminating the 'intervening gaps', into the belief in eternally existent, imperishable gods. ${ }^{73}$ Seemingly comparable is $D R N$ 5.1175-76: 'they [i.e., the earliest humans as they see gods in their sleep] give them immortal life, because their images presented themselves in constant succession and their forms remained unchanged'.

This passage of Cicero is not only less than clear in its description but its 'idealist' interpretation is also at odds with the transmitted words of Epicurus himself. Epicurus' own words are unam-

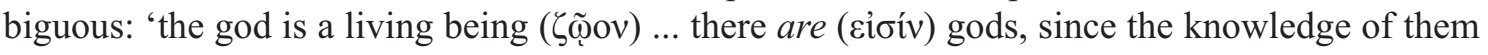

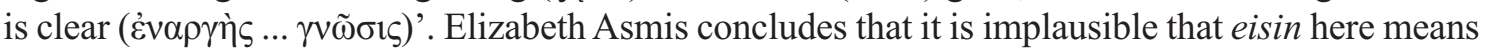
anything other than 'exist' objectively. ${ }^{74}$ As Jacob Mackey argues in a forthcoming paper, the disagreement surrounding the theology of the atomist or Epicurean writers is due in part to the fact that those writers were not trying to answer the question we want them to address. They are concerned less with explaining the true nature of the gods in an ontological sense; they are, instead, more concerned with accounting for how humans know about the gods, which is an epistemological question. The existence of the gods is not something that those ancient writers tried to prove through logical argument. It is instead something they accept on the basis of reports of human perceptual experience - dream imagery and ordinary visual perception. Votive reliefs, I am suggesting, correspond to the materialist theory in their emphasis on the importance of human perceptual experience of the gods, as well as in their visual descriptions of them.

\section{On the magnitude of the gods in the materialist tradition}

'Idealists take Epicurus' idea to have been ... that gods are our own graphic idealization of the life to which we aspire'. ${ }^{75}$ Important features of the Epicurean gods can indeed be related to other values within Epicurean ethics. It is well known, for example, that the self-sufficiency and contentment attributed to the gods are qualities that mortals should emulate in order to achieve the goal of ataraxia. ${ }^{76}$ One can understand how inferences about the happiness of the gods might have been shaped by didactic goals; but that 'means-ends' way of thinking cannot account for one standard feature of the gods within atomist and Epicurean thought: their over-life-size stature.

The magnitude of the gods is repeatedly mentioned in accounts of materialist theology. In describing the gods of Demokritos, in two different places, Sextus Empiricus explicitly notes their large size: 'gigantic images (huperphuē) in human shape' (9.42); 'these are huge and gigantic (megala te kai huperphuē) and difficult to destroy' (9.19). In one passage of Cicero (Nat. D. 1.43 [120]), the gods of Demokritos are ridiculed as being of such enormous size (ingentis imagines) as to enfold the entire world. In the words of Epicurus that come down to us, the qualities of the 23F.2.

71 Sext. Emp. 9.45, tr. after Long and Sedley (1987)

72 Long and Sedley (1987) 1.23.

73 Purinton (2001) 183 and passim. Purinton's interpretation has been accepted by Sedley (2011) 46 n.46. 
gods singled out are blessedness and imperishability; but Sextus, as noted in the introduction, attests that size is also fundamental (9.43). Lucretius identifies size as perhaps the most fundamental criterion of the gods: 'even in remote antiquity, the minds of mortals were visited in waking life, and still more in sleep, by visions of divine figures "dazzling in the marvellous size of their bodies, mirando corporis auctu". ${ }^{77}$

In the $D R N$, the large size of the gods is the one feature identified as arising from the primary visual (videbant) encounter experienced by humans from the beginning of time. The other features of the gods in the Lucretian account are inferences drawn by people about the gods (5.1172-82):

to these beings they attributed sensation, because they saw them move their limbs and speak in a majestic manner appropriate to their splendid appearance and ample strength. They gave them immortal life, because their images presented themselves in constant succession and their forms remain unchanged ... And they regarded them as consummately happy, because fear of death did not trouble any of them and also because in sleep they saw them perform marvellous feats without experiencing any fatigue. ${ }^{78}$

In this theology, large size is a fundamental and definitive feature of the gods, preceding any analysis. The consistently larger size of the gods and goddesses, in comparison to the human scale provided by mortal worshippers, in votive reliefs (fig. 1, etc.) corresponds perfectly to the atomist and Epicurean understanding of the magnitude of the gods. The conception of the gods represented in votive reliefs may be worlds apart from the unanthropomorphic conceptions of god in Xenophanes, Plato or Aristotle, but it is not the case that they bear no comparison to sophisticated philosophical thought. It is just that they bear close comparison to a strain of ancient philosophy, materialist thought, that has arguably been neglected by art historians in favour of idealist philosophy.

\section{$X$. Artistic representation and the formation of materialist thought: some concluding spec- ulations}

Many aspects of the historical relationship between materialist theology and Classical votive reliefs elude investigation. How many votive reliefs, if any, Demokritos, Epicurus or Lucretius might have looked at, or what they might have thought about them, we cannot say on the basis of the information available to us. There are, however, some indirect indications of interest in artistic representations of gods. Chris Eckerman observes that the important statement in book 6 of the $D R N$, mentioned above, which unambiguously asserts the existence of gods in bodily form, is framed in a suggestive way: '[unless you free your mind from incorrect inferences about the gods] you will be unable to approach their shrines with an untroubled breast; and you will be impotent to receive in peace and tranquillity the images that emanate from their sacred bodies and enter human minds with news of divine beauty' (6.75-78). In antiquity, religious shrines regularly contained artistic images of the gods. Eckerman argues that, in this passage, Lucretius is suggesting that humans get their concepts of the corpore sancto from the statues they saw in their shrines. ${ }^{79}$ While I believe that the passage unambiguously implies that corpore sancto are living bodies, Eckerman's observation suggests that, for Lucretius, the statues in a religious shrine are not necessarily incompatible with the 'news of divine beauty', which emanates directly from the bodies of the gods. Eckerman calls attention to one other Epicurean reference to artistic representations of gods. In On Piety, Philodemos writes: 'we observe that people have always represented Hermes as rectangular (i.e., as a herm). And yet to be born with an odd shape, or suffer mutilation to any of one's parts later, need not involve any wickedness; but to represent the gods as most depraved

77 The translation reflects the language of both Smith (2001) and Mackey (forthcoming). Bailey translates the key words, mirando corporis auctu, 'with wondrous bulk of body'.

\footnotetext{
78 The Latin text is given in the introduction above.

79 Eckerman (2019). I thank the author for sharing his paper with me prior to its appearance in print.
} 
right from their birth [as in Homer's characterization of Ares] is impious ... ${ }^{80}$ Noteworthy in this passage is the absence of any implication that the artistic representation of Hermes is a false inference, even though it is rectangular in form.

As an example of an artistic visualization of the gods accepted as truthful by Lucretius, consider a passage from book 3 :

As soon as your philosophy begins to proclaim the true nature of things ... the terrors of the mind are dispelled, the walls of the world dispart, and I see what happens throughout the whole void. Plainly visible are the gods in their majesty, and their calm realms which, buffeted by no wind, sprinkled by no storm cloud's shower, sullied with no white fall of snow crystallized by biting frost, are ever pavilioned by a cloudless ether that smiles with widespread flood of radiance (3.14-22) ${ }^{81}$

In this description of the tranquil abode of the gods, the expressions 'buffeted by no wind, sprinkled by no storm cloud's shower, sullied with no white fall of snow' correspond exactly to a description of the home of the gods in Homer's Odyssey (6.42-45, tr. Lattimore): 'so the gray-eyed Athene spoke and went away from [Nausikaa] to Olympos, where the abode of the gods stand firm and unmoving forever, they say, and is not shaken with winds nor spattered with rains, nor does snow pile ever there'. ${ }^{82}$ Of course, the intertextual reference was a way for Lucretius, composing an epic poem in the dactylic hexameter meter of Homeric epic, to enter into competition with Homer and correct his theology (deities do not visit the bedrooms of teenage girls). ${ }^{83}$ For my purposes, however, the important point is that the Homeric image of the home of the gods is given an entirely positive interpretation by Lucretius; there is no hint that he understood it as a false inference. It is as if he accepted this particular image as a record of Homer's own, authentic perception of the gods. ${ }^{84}$

Indeed, it was suspected in antiquity that artistic images played a role in the formulation of Epicurean theology. In his critique in Cicero's De natura deorum (see especially 1.29 [75-83]), the anti-Epicurean spokesman Cotta argues that the anthropomorphic form of the Epicurean gods is nothing other than the traditional anthropomorphic form given to the gods in art: 'Very likely we Romans do imagine god as you say, because from our childhood Jupiter, Juno, Minerva, Neptune, Vulcan and Apollo have been known to us with the aspect with which painters and sculptors have chosen to represent them' [81]. ${ }^{85}$ What is hard to know is whether Cotta, for whom god is a conceptual thing and not a material body, is comparing the Epicurean gods to works of art as a put-down or utilizing an analogy developed by the Epicureans themselves.

\section{Bibliography}

Asmis, E. (2009) 'Epicurean empiricism', in J. Warren (ed.), The Cambridge Companion to Epicureanism (Cambridge) 84-104

Babut, D. (2005) 'Sur les dieux d’Épicure', Elenchos 26, 79-110

Bailey, C. (1947) Titi Lucreti Cari: De Rerum Natura (Oxford)

${ }^{80}$ Phld. On piety col. $199=$ PHerc. 1088 fr. 10 , lines

5-30, text and tr. after Obbink (2001) 194.

81 nam simul ac ratio tua coepit vociferari naturam rerum, divina mente coortam, diffugiunt animi terrores, moenia mundi discedunt, totum video per inane geri res. apparet divum numen sedesque quietae quas neque concutiunt venti nec nubila nimbis aspergunt neque nix acri concreta pruina cana cadens violat semperque innubilus aether integit, et large diffuso lumine ridet.

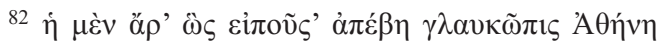

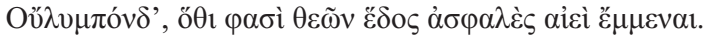

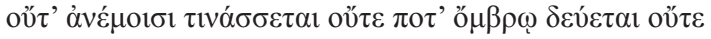
$\chi 1 \omega ̀ v \dot{\varepsilon} \pi ı \pi \hat{\imath} \lambda v \alpha \tau \alpha 1$.

${ }^{83}$ So, for example, Campbell (2014) 34.

${ }^{84}$ For a somewhat different reading, see Obbink (1989) 197. See also Eckerman (2019).

${ }^{85}$ Nobis fortasse sic occurrit ut dicis; a parvis enim Iovem Iunonem Minervam Neptunum Vulcanum Apollinem reliquos deos ea facie novimus qua pictores fictoresque voluerunt. 
Baumer, L.E. (1997) Vorbilder und Vorlagen: Studien zu klassischen Frauenstatuen und ihrer Verwendung für Reliefs und Statuetten des 5. und 4. Jahrhunderts vor Christus (Bern)

Berger, E. (1970) Das Basler Arztrelief (Basel)

Blickman, D. (1989) 'Lucretius, Epicurus, and prehistory', HSPh 92, 157-91

Burkert, W. (1977) 'Air-imprints or eidola: Democritus' aetiology of vision', ICS 2, 97-109

- (1997) 'From epiphany to cult statue: early Greek theos', in A.B. Lloyd (ed.), What is a God? Studies in the Nature of Greek Divinity (London)

Campbell, G. (2014) 'Lucretius, Empedocles and Cleanthes', in M. Garani and D. Konstan (eds), The Philosophizing Muse: The Influence of Greek Philosophy on Roman Poetry (Cambridge) 26-60

Clay, D. (1980) 'An Epicurean interpretation of dreams', AJPh 101, 342-65

Comella, A. (2002) I rilievi votivi greci di periodo arcaico e classico: diffusione, ideologia, committenza (Bari)

Dinsmoor, W.B. (1921) 'Attic building accounts IV: the statue of Athena Promachos', AJA 25, 118-29

Eckerman, C. (2019) 'Lucretius on the divine: DRN 3.17-30, 5.1161-93, and 6.68-79', Mnemosyne 72, 284-99

Edelmann, M. (1992) Menschen auf griechischen Weihreliefs (Munich)

Edwards, C.M. (1985) Greek Votive Reliefs to Pan and the Nymphs (Ph.D. Diss. New York)

Elsner, J. (2007) Roman Eyes: Visuality and Subjectivity in Art and Text (Princeton)

Ferwenda, R. (1972) 'Democritus and Plato', Mnemosyne 25, 337-78

Foxhall, L. and Barfoed, S. (2015) Miniaturization, World Archaeology 47 (special issue)

Gaifman, M. (2012) Aniconism in Greek antiquity (Oxford)

- (2016) 'Theologies of statues in Classical Greek art', in E. Eidinow, J. Kindt and R. Osborne (eds), Theologies of Ancient Greek Religion (Cambridge) 249-80

Gordon, R.L. (1979) 'The real and the imaginary: production and religion in the Graeco-Roman world', Art History 2, 5-34

Guralnick, E. (1974) 'The Chrysapha relief and its connections with Egyptian art', JEA 60, 175-88

Hausmann, U. (1960) Griechische Weihreliefs (Berlin)

Hedreen, G. (2001) Capturing Troy: The Narrative Functions of Landscape in Archaic and Early Classical Greek Art (Ann Arbor).

- (2011) 'The Trojan War, Theoxenia, and Aigina in Pindar's sixth Paian and the Aphaia sculptures', in D. Fearn (ed.), Songs for Aigina: Contextual Studies of Pindar and Bacchylides (Oxford) 323-69

Himmelmann, N. (1998a) 'The divine assembly on the Sosias cup', in H.A. Shapiro (tr.) and W. Childs (ed.), Reading Greek Art: Essays by Nikolaus Himmelmann (Princeton) 139-55

- (1998b) 'Some characteristics of the representation of gods in Classical art', in H.A. Shapiro (tr.) and W. Childs (ed.), Reading Greek Art: Essays by Nikolaus Himmelmann (Princeton) 103-38

Hölscher, F. (2012) 'Gods and statues: an approach to archaistic images in the fifth century BCE', in J. Mylonopoulos (ed.), Divine Images and Human Imaginations in Ancient Greece and Rome (Leiden) $105-20$

- (2017) Die Macht der Gottheit im Bild: archäologische Studien zur griechischen Götterstatue (Heidelberg)

Kaltsas, N. (tr. D. Hardy) (2002) Sculpture in the National Archaeological Museum, Athens (Los Angeles)

Kirk, G.S. (1990) The Iliad: A Commentary 2: Books 5-8 (Cambridge)

Klöckner, A. (2010) 'Getting in contact: concepts of human-divine encounter in Classical Greek art', in J.N. Bremmer and A. Erskine (eds), The Gods of Ancient Greece: Identities and Transformations (Edinburgh) $106-25$

- (2015) 'Herakles und der Viersäulenbau', Marburger Winckelmann-Programm 2015, 49-62

Konstan, D. (2011) 'Epicurus on the gods', in J. Fish and K. Sanders (eds), Epicurus and the Epicurean Tradition (Cambridge) 53-71

Laks, A. and Most, G.W. (eds and trs) (2016) Early Greek Philosophy (Cambridge MA)

Lattimore, R. (tr.) (1967) The Odyssey of Homer (New York)

Lawton, C. (2007) 'Children in Classical Attic votive reliefs', in A. Cohen and J. Rutter (eds), Constructions of Childhood in Ancient Greece and Italy (Princeton) 41-60

Long, A.A. and Sedley, D.N. (1987) The Hellenistic Philosophers (Cambridge)

Mackey, J. (forthcoming) 'Saving the appearances: the phenomenology of epiphany in atomist theology and religious history', Invigilata Lucernis 
Mansfield, J. (1993) 'Aspects of Epicurean theology', Mnemosyne 46, 172-210

Mikalson, J.D. (2010) Greek Popular Religion in Greek Philosophy (Oxford)

Neer, R.T. (2017) 'Was the Knidia a statue? Art history and the terms of comparison', in J. Elsner (ed.), Comparativism in Art History (London) 145-64

Neumann, G. (1965) Gesten und Gebärden in der griechischen Kunst (Berlin)

- (1979) Probleme des griechischen Weihreliefs (Tübingen)

Nightingale, A. (2016) 'Sight and the philosophy of vision in Classical Greece: Democritus, Plato and Aristotle', in M. Squire (ed.), Sight and the Ancient Senses (Abingdon) 54-67

O’Keefe, T. (2014) Ancient Philosphies: Epicureanism (Abingdon)

Obbink, D. (1989) 'The atheism of Epicurus', GRBS 30, 187-223

- (2001) “"All gods are true” in Epicurus', in D. Frede and A. Laks (eds), Traditions of Theology (Leiden) $183-221$

Osborne, R. (2011) The History Written on the Classical Body (Cambridge)

Palagia, O. (1995) 'Akropolis Museum 581: a family at the Apaturia?', Hesperia 64, 493-501

Payne, H. and Young, G.M. (1936) Archaic Marble Sculpture from the Acropolis: A Photographic Catalogue (London)

Petridou, G. (2015) Divine Epiphany in Greek Literature and Culture (Oxford)

Platt, V. (2011) Facing the Gods: Epiphany and Representation in Graeco-Roman Art, Literature and Religion (Cambridge)

- (2016) 'Sight and the gods: on the desire to see naked nymphs', in M. Squire (ed.), Sight and the Ancient Senses (Abingdon) 161-79

Porter, J.I. (2010) The Origins of Aesthetic Thought in Ancient Greece: Matter, Sensation, and Experience (Cambridge)

Purinton, J. (2001) 'Epicurus on the nature of the gods', OSAPh 21, 181-231

Rauscher, H. (1971) Anisokephalie: Ursache und Bedeutung der Grössenvariienrung von Figuren in der griechischen Bildkomposition (Vienna)

Richardson, N.J. (ed.) (1974) The Homeric Hymn to Demeter (Oxford)

Roberts, J.L. (2016) 'Introduction: seeing scale', in J.L. Roberts (ed.), Scale (Chicago) 10-24

Robertson, M. (1975) A History of Greek Art (Cambridge)

Rose, H.J. (1956) 'Divine disguisings', HThR 56, 63-72

Rudolph, K. (2016) 'Sight and the Presocratics: approaches to visual perception in early Greek philosophy', in M. Squire (ed.), Sight and the Ancient Senses (Abingdon) 36-53

Salapata, G. (2014) Heroic Offerings: The Terracotta Plaques from the Spartan Sanctuary of Agamemnon and Kassandra (Ann Arbor)

Sedley, D. (1992) 'Empedocles' theory of vision and Theophrastus' De Sensibus', in W.W. Fortenbaugh and D. Gutas (eds), Theophrastus: His Psychological, Doxographical and Scientific Writings (New Brunswick) 20-31

- (1998) Lucretius and the Transformation of Greek Wisdom (Cambridge)

- (2011) 'Epicurus' theological innatism', in J. Fish and K. Sanders (eds), Epicurus and the Epicurean Tradition (Cambridge) 29-52

Shapiro, H.A. (2003) 'Fathers and sons, men and boys', in J. Neils and J.H. Oakley (eds), Coming of Age in Ancient Greece: Images of Childhood from the Classical Past (New Haven) 85-111

- (2014) 'Votive relief and vase-painting: an archaeological Kreuzung der Gattungen in Classical Athens', Marburger Winckelmanns Programm 2014, 57-66

Simon, E. (1977) 'Criteri per l'esegesi dei pinakes locresi', Prospettiva 10, 15-21

- (1980) Die Götter der Griechen (Munich)

- (2016) Opfernde Götter (rev. edition) (Dettelbach)

Smith, M.F. (tr.) (2001) Lucretius: On the Nature of Things (Indianapolis)

Squire, M. (ed.) (2016) Sight and the Ancient Senses (London)

Steiner, D. (2001) Images in Mind: Statues in Archaic and Classical Greek Literature and Thought (Princeton)

Stewart, A. (2016) 'The Borghese Ares revisited: new evidence from the Agora and a reconstruction of the Augustan cult group in the Temple of Ares', Hesperia 85, 577-625

Tanner, J. (2006) The Invention of Art History in Ancient Greece: Religion, Society and Artistic Rationalisation (Cambridge) 
Taylor, C.C.W. (1999) The Atomists: Leucippus and Democritus (Toronto)

Turkeltaub, D. (2007) 'Perceving Iliadic gods', HSPh 103, 51-81

Van Straten, F.T. (1976) 'Daikrates' dream: a votive relief from Kos, and some other kat'onar dedications', BABesch 51, 1-38

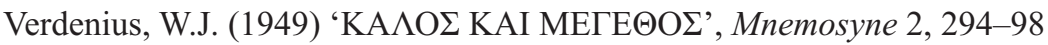

Vikela, E. (2004) 'The iconography of donors on votive reliefs', in V. Lambrinodakis and J.C. Balty (eds), Thesaurus Cultus et Rituum Antiquorum 1 (Los Angeles) 284-87

- (2005) 'Griechische Reliefweihungen an Athena: Ikonographie der Göttin und Bildkomposition der Reliefs', $\operatorname{MDAI}(A)$ 120, 85-161

Wace, A.J.B. (1937) 'A Spartan hero relief', AEph 76, 217-20 